\title{
A MEDIEVAL HEBREW TREATISE ON OBSTETRICS
}

\author{
by
}

\section{RON BARKAI*}

Recent years have shown an increasing interest in the history of medicine. This is no longer a distant, estranged branch of study, reserved for a handful of specialists, but an important part of the framework encompassing the study of the past. An especially vital facet of this discipline is the history of women's medicine, from which much can be learned concerning the ways in which our forebears viewed the physiological and mental differences between men and women, the formation of life within the womb, and the birth process itself. ${ }^{1}$

As in other areas of medieval science, researchers in this field must consider not only the ancient Greek and Latin sources, but the mutual influences and exchange of medical information among the Muslim, Jewish, and Christian cultures. The gynaecological literature written in Latin Europe during the Middle Ages has, to date, been given considerable coverage in academic studies. This refers mainly to the two most popular treatises of the Middle Ages and the Renaissance, both attributed to Trotula, a woman doctor and lecturer at the Salerno school of medicine: Trotula minor and Trotula major. ${ }^{2}$

The Muslim gynaecological literature has thus far not been studied nearly so widely as the Latin. Nevertheless, the most important treatise in this area, written in the tenth century by 'Arib ibn Sa'id of Cordova, has been published and translated into French

* Dr Ron Barkai, Department of History, Tel Aviv University, Ramat-Aviv, 69978 Tel Aviv, Israel.

${ }^{1}$ A striking example of this type of study is Danielle Jacquart and Claude Thomasset, Sexualité et savoir médicale au moyen âge, Paris, Presses universitaires de France, 1985. Gynaecological literature is an important component of Ian Maclean, The Renaissance notion of woman, Cambridge University Press, 1980. The changes in the concept and status of women in the early modern era, as borne out by medical treatises, are attested to in: Audrey Eccles, Obstetrics and gynaecology in Tudor and Stuart England, London, Croom Helm, 1982. For the ancient sources of concepts and views about women and the differences between the sexes, see mainly: G. E. R. Lloyd, Science, folklore and ideology: studies in the life sciences in ancient Greece, Cambridge University Press, 1983.

2 John F. Benton recently showed that the treatises traditionally attributed to Trotula actually consisted of three different works, none of them written by her. The incipits of these tracts are Ut de curis, Cum auctor, and De ornatu. 'Trotula, women's problems, and the professionalization of medicine in the Middle Ages', Bull. Hist Med., 1985, 59: 30-53; for a description of the three tracts, see pp. 32-6. At the same time, Benton reached the conclusion that a woman doctor named Trotula did indeed write a gynaecological treatise, whose incipit is Practica secundum Trotam; this work, however, did not achieve the great popularity enjoyed by the treatises attributed to Trotula. It should also be noted that the study of medieval gynaecological literature up to the twelfth century was significantly advanced by the appearance of M. H. Green's 'The transmission of ancient theories of female physiology and disease through the Middle Ages', Ph.D. dissertation, Princeton University, 1985. 
and Spanish. ${ }^{3}$ Several important studies have indicated the influence of Greek and Latin sources on Arab literature. However, there can be no doubt that Muslim gynaecology still requires more comprehensive research. ${ }^{4}$

By contrast, research into women's medicine among medieval Jewry remains virtually a virgin field: the overwhelming majority of texts have been neither studied nor published. ${ }^{5}$ This fact prevents us from appreciating the role played by Jews in this field, whether as translators and conveyers of knowledge or for their own unique contribution to that science.

The Jewish medical literature of the early Middle Ages was generally written in Arabic or Judaeo-Arabic (Arabic written in Hebrew letters, with the addition of Hebrew and Aramaic expressions). ${ }^{6}$ Starting in the second half of the twelfth century, with the rising number of Jews exiled from al-Andalus under the fanatical rule of the Almohads, more and more medical treatises were translated into Hebrew, and some were even written originally in that language. ${ }^{7}$ Among the Jewish doctors writing

\footnotetext{
3 'Arib ibn Sa'id al-Kātib al-Qurtubī, Kitäb khalq al-janin wa-tadbïr al-habālā wa-l-mawludin, Le livre de la génération du foetus et le traitement des femmes enceintes et des nouveau-nés, publié, traduit et annoté par $\mathrm{H}$. Jahier et A. Noureddine, Alger, Publication de la Faculté mixte de Médecine et de Pharmacie d'Alger, 1956. A short description of the treatise was given by Jahier in: Archo iberoamericano Hist. Med., 1956, 8: $163-6$. The treatise was translated into Spanish by: A. A. Castro, El libro de la generación del feto, el tratamiento de las mujeres embarazadas y los recien nacidos, Cordoba, Publ. de la excma. disputación provincial, 1983. Although 'Arib ibn Sa'id's work is dedicated mainly to obstetrics and neonatology, it contains important information of gynaecology, male-female differences, etc., taken from Greek, Persian, Indian, and Arabic sources.

${ }^{4}$ A pioneer study in this field is that of Max Meyerhof and D. Joannidès, La gynécologie et l'obstetrique chez Avicenne (Ibn Sina) et leurs rapports avec celles des Grecs, Cairo, E. \& R. Schindler, 1938; idem., La gynécologie et l'obstetrique de Paul d'Égine et son influence sur la médecine arabe, Cairo, 1940. On the chapters on gynaecology and obstetrics in the work of at-Tabari (ninth century), see A. Siggel, 'Gynäkologie, Embriologie und Frauenhygiene aus dem Paradies der Weisheit über die Medizin des Abū Hassan 'Alī b. Sahl Rabban at-Tabari nach der Ausgabe von Dr. Zubair as-Siddiqi', Quellen u. Stud. Gesch. Naturw. u. Med., 1941, 8: 216-72. On concepts held by Albucasis (Halaf ibn 'Abbās az-Zahrāwī, d. 1013), see: S. Remo, 'Ostetria e ginecologia nel bizantino Paolo d'Egina è nell'arabo Albucasis', Minerva Medica, 1967, 58: 4118-31. One of the most important Muslim doctors whose work influenced Latin gynaecology was 'Ali ibn 'Abbas al-Majūsī (d. 1009), known throughout the West as Haly Abbas. See: A. A. Gewargis, Gynäkologisches aus dem Kämil as-Sina'a at-Tibbìya des 'Ali ibn al-'Abbäs al-Majüsi: Die Abschnitte über Anatomie, Pathologie und konservative Therapie des nichtschwangeren Uterus, inaugural dissertation, University of Nuremberg, 1980. On the influence of Muslim gynaecological treatises on the Latin West, see Green, op. cit., note 2 above, especially chapters 2 and 4.

${ }^{5}$ Exceptional is the case of Maimonides. See: I. M. Lewinger, 'The structure of the female reproductive systems in humans and cattle (an explanation of the Mishnah-Niddah 2/5)', Koroth, 1968, 4: 611-15 (Hebrew); W. Steinberg and S. Muntner, 'Maimonides' views on gynaecology and obstetrics-English translation of chapter sixteen of his "Pirke Moshe” (Medical Aphorisms)', Am. J. Ostet. and Gynec., 1965, 91: 443-8.

${ }^{6}$ See the important bibliographical survey of Arabic works written by Jews, including medical treatises, compiled by Moritz Steinschneider, Die arabische Literatur der Juden, Biblioteca Arabic-Judaica, Frankfurt-on-Main, 1902.

${ }^{7}$ On the Hebrew translation made in the high and later Middle Ages, see idem, Die hebräischen Übersetzungen des Mittelalters und die Juden als Dolmetscher, Berlin, 1893, repr. Graz, Akademische Druck u. Verlagsanstalt, 1956. On the problem of medical terms translated from Arabic to Hebrew, see $\mathbf{H}$. Kroner, Zur Terminologie der arabischen Medizin und ihren zeitgenossischen hebräischen Ausdrucke, Berlin,
} 
gynaecological literature, the only one who can be definitely identified is Ššet ben Yitzhaq ben Yosef Benveniste, who was apparently born in Narbonne, lived and worked in Barcelona and Saragossa, and died the latter city in $1209 .^{8}$ Sešet Benveniste wrote in Arabic; his treatise was translated into Hebrew shortly afterward by al-Harizi. Two fragments of the Hebrew manuscript have come down to us, one entitled Refu'a le-Herayon (Medicament for pregnancy), ${ }^{9}$ and other Terufot $u$-Mirqahot le-Mahalot Našim (Medicaments and confections for women's diseases). ${ }^{10}$

We are also familiar with several gynaecological treatises whose authors or translators cannot yet be definitely identified. The earliest of these, apparently dating from the thirteenth century, bears the Hebrew title Sefer Dina le-Khol 'Inyan ha-Rehem ve-Holayeha (The book of Dina on all the problems and diseases of the womb). ${ }^{11}$ The treatise itself is written in Judaeo-Arabic, and includes prescriptions for uterine diseases, menstrual problems, and difficulties of parturition. The manuscript which has come down to us consists of only two folios, and is apparently only part of an originally more expansive work. Although the treatise is entitled The book of Dina, its contents include no explanation of that name. This explanation may be found in another work, entitled Sefer ha-Toledet (Book on generation). This treatise, which exists in three complete manuscripts, ${ }^{12}$ was identified by Steinschneider as a Hebrew translation of Muscio's Gynaecia. ${ }^{13}$ In fact, this is a Hebrew adaptation of the Latin text, as the adapter implemented certain changes in the structure of the original composition and made frequent use of Biblical expressions and ideas. This treatise maintained the form of questions and answers to be found in the Latin original, but converted it into a dialogue between a father and his daughter, whose name was Dina (according to one version of the manuscript, the speakers are the Biblical Jacob and his daughter Dina). An interesting section of the Hebrew work is its opening passage, which does not appear in the Latin treatise. Its incipit reads: "After God created man

Ibzkowski, 1921. Cf. Harry Friedenwald, 'The use of the Hebrew language in medical literature', Bull. Inst. Hist. Med., 1934, 2: 77-111; reprinted in his collected essays The Jews in medicine, Baltimore, Johns Hopkins Press, 1944, vol. 1, pp. 146-80.

${ }^{8}$ George Sarton, Introduction to the history of science, Baltimore, Williams \& Wilkins for the Carnegie Institution of Washington, 1931, p. 604; Friedenwald, Jews in medicine, op. cit., note 7 above, vol. 2, pp. 659-60.

${ }^{9}$ Oxford, Bodleian Library, Ms. 2142, no. 2.

${ }^{10}$ Oxford, Bodleian Library, Ms. 2142, no. 24. Neither treatise is mentioned by Steinschneider.

${ }^{11}$ London, British Library, Ms. or. 10539, no. 4 (Gaster, 939).

12 One manuscript is in London, British Library, Montefiore, Ms. 420, no. 2 (Halberstam, Ms. 253); the second is in Rome, Casanatense Library, J. IV. 5; the third is in the Vatican, Ms. hebr. 366, no. 5. For the description of these manuscripts, see: Steinschneider, op. cit., note 7 above, vol. 2, pp. 810-11; and his preliminary study of these tracts: 'Medicinische Handschriften', Mag. Wiss. Judenthums, 1883, 10: 103-8, 157-9.

${ }^{13}$ On Muscio and his work, see Martin von Schanz, C. Hosius, and Gustav Krüger, Geschichte der römischen Literatur bis zum Gesetzgebungswerk des Kaisers Justinian, 4, vol. 2, Die Literatur des fünften und sechsten Jahrhunderts, Munich, 1920, pp. 289-91; Green, op. cit., note 2 above, pp. 136-9. His treatise, a Latin translation of Soranus' Gynaecology, was published by V. Rose, Sorani Gynaeciorim vetus translatio latina, Leipzig, B. G. Teubner, 1882. It has been reprinted, with an Italian translation, in R. Radicchi, La 'Gynaecia' de Muscione: manuale per le ostetriche e le mamme del VI sec. d.C., Pisa, Editrice Giardini, 1970. I used Rose's edition. 
[made of] dust from the earth...", which resembles that of the Cum auctor tract. However, examination of the introductions to the two treatises shows that, aside from the similarity of the first sentence, they are not at all related. ${ }^{14}$

At this stage, it is difficult to state whether the treatise was adapted from a Latin original alone, or whether an Arabic text was used as a secondary source. The latter supposition arises from the fact that, while the adapter made use of many Greek and Latin medical terms in Hebrew transliteration, others-especially those relating to materia medica-are influenced by the Arabic. ${ }^{15}$

We have no direct evidence of the translator's identity, or even of the century in which he lived (the three extant manuscripts date from the fourteenth to the sixteenth centuries). It is, however, possible that the key to the mystery lies in the last line of the treatise, which reads: "And Dina went out from before her father, and her husband Ayyub [or Iyov] knew her, and sons and daughters were born."16 As the manuscripts contain no vowel signs, the name of Dina's husband (written aleph, yod, waw, bet) may be that of the Biblical Job. On the other hand, it may be the colophon left by the author-translator, in which case it should be read as "Ayyub". It also seems to me that a thorough examination of the relationship between this work and The book of Dina might supply clearer details on the period and sources of the treatise.

Another Hebrew work, based on the Galenic medical tradition, is entitled Sefer ha-Em el Galinus hu ha-Niqra Gynias (The book on the matrix by Galen, which is called Gynaecias). ${ }^{17}$ Two complete manuscripts of this treatise have survived to this day. ${ }^{18}$

The treatise called Zikhron ha-Holayim ha-Hovim bi-Khley ha-Herayon (Recollection [about] the diseases occurring in the generative organs), to the best of our knowledge, now exists in one manuscript only. ${ }^{19}$ It deals with medical problems and diseases affecting both men and women and causing sterility. Most of the work is devoted to regulation of the menses and treatment of a series of diseases affecting the uterus. Here, too, it is difficult to determine the sources of the treatise, as it contains a mixture of terms and concepts drawn from the Greek, the Latin, and the Arabic. The work itself is in the nature of a practical text book, with nearly no discussion of the theoretical aspects of gynaecology.

Alongside this list of works which, while still unresearched, are known and recognized, there are additional Hebrew-language treatises dealing with gynaecology and obstetrics to which no scholarly attention has yet been directed. The remainder of this article will be devoted to one of these.

\footnotetext{
${ }^{14}$ For this comparison, I consulted the Cum auctor version of Ms. Lat: 7056, f. 77rb. of the Bibliothèque Nationale, Paris.

${ }^{15}$ I am now working on a critical edition of this treatise. I hope that the study will enable us to determine its sources.

${ }^{16}$ British Library, Montefiore, Ms. 420, f. 53r.

${ }^{17}$ For a description of this treatise, see: Steinschneider, op. cit., note 7 above, vol. 2, p. 656; and idem, 'Medicinische Handschriften', op. cit., note 12 above, pp. 108-12.

18 British Library, Montefiore, Ms. 240, ff. 53v.-62v.; Parma, Biblioteca Palatina, Ms. 2646 (Rossi 1316).

${ }^{19}$ British Library, Montefiore, Ms. 420, ff. 15v.-25v. Cf. Steinschneider, 'Medicinische Handschriften', op. cit., note 12 above, p. 103.
} 
The work in question is a chapter entitled Miqoši ha-Leda (On difficulties of birth), which exists in a fourteenth-century manuscript which itself constitutes a fragment of a medical treatise. From the chapters remaining of this work - two of which deal with laxatives-it may be seen that its scope was not limited to women's medicine. Nevertheless, women's medicine was obviously one of its main topics: aside from the chapter on difficulties of parturition, it contains a chapter on the extraction of the placenta after birth, and a chapter devoted to uterine diseases. ${ }^{20}$ The chapter Miqosi ha-Leda also exists in a collection of fourteenth and fifteenth-century medical manuscripts in the Bibliothèque Nationale in Paris. ${ }^{21}$ Unlike the former manuscript, kept in London, the Paris manuscript, here referred to as "Ms.P", is not damaged and may be deciphered in its entirety. Aside from the textual differences, Ms. $P$ is of extreme importance to the history of Hebrew obstetrics, as it is accompanied by sixteen drawings of foetuses in the womb. ${ }^{22}$ To the best of my knowledge, this is the only Hebrew-language manuscript to which such drawings are appended.

Given the advantages of Ms.P, I have chosen to translate that manuscript into English (see appendix), and to cite the variants in the London manuscripts ("Ms. $L$ ") in notes to this translation. In addition to translating the Hebrew text, I intend to draw the reader's attention to several concepts and treatment procedures existing in the Hebrew tract-some of them typical of medieval medicine, and others relatively uncommon at the time. I shall also comment on the medical views and treatment practices described in this tract, from the standpoint of modern medical obstetrics.

The Hebrew tract differentiates between three types of births: (1) "natural birth", or normal labour; (2) "unnatural birth", where delivery involves pathological presentations; and (3) "difficult birth", where delivery causes suffering to mother or foetus. This differentiation is not unique to the Hebrew treatise; its sources may be found in ancient and early medieval medical manuscripts. In Muscio's sixth-century Latin translation of a second-century gynaecological treatise by the Greek physician Soranus, ${ }^{23}$ the three types of births are described in the very same terms later used by the Hebrew author: (1) adversa et contra naturam; (2) secundum naturam; (3) cum difficultate. ${ }^{24} \mathrm{~A}$ classification different in terminology but identical in content may be found in "Arib ibn Sa'id's work: "Difficulties of birth may result from three directions: those concerning the labouring of women, the foetus, or external factors." 25 The Hebrew adaptation of Muscio's treatise uses similar terms. In answer to a question by

\footnotetext{
${ }^{20}$ British Library, Ms. or. 10766, the chapter On Birth Difficulties, ff. 9r.-9v. I will refer to this version as Ms. L.

${ }^{21}$ Paris, B.N., Ms. Heb. 1120, ff. 66r.-67r. Cf. Catalogues des manuscrits hébreux et samaritains de la Bibliothèque Impériale, Paris, 1866, p. 207. I will refer to this version as Ms.P.

${ }_{22}$ Ms. $P$, ff. 67v. $-70 \mathrm{r}$.

${ }^{23}$ On Soranus' Gynaecology, see Lloyd, op. cit., note 1 above, pp. 168-200; Owsei Temkin, Soranus' Gynecology, Baltimore, Johns Hopkins Press, 1956; Green, op. cit., note 2 above, pp. 23-36.

24 Sorani gynaecia, op. cit., note 13 above, p. 79.

25 'Arib ibn Sa'id, Kitäb khalq al-janin, op. cit., note 3 above, p. 47 (Arabic text). A similar categorization of birth was given by Paul of Aegina: "Difficultas pariendi fit aut propter parientem aut propter id, quod paritur, aut propter intestinum aut propter ea qui extrinsecus", Pauli Aeginetae libri tertii interpretatio latina antiqua, edited by J. L. Heiberg, Leipzig, B. G. Teubner, 1912, p. 193. It is repeated by Rhazes in Kitäb al-Hawi; see his chapter on 'Difficulties of birth': Muhammad Kämel Hussein and Muhammad 'Abd-al-Halim al-'Uqabī, Ṭib ar-Rāzì, dirāsat wa-tahlil li-kitäb al-hawì, Beirut, 1977, p. 413.
} 
Dina, her father explains that difficulties of birth have two types of causes: "one caused by the foetus, and the other caused by the labouring woman". He later adds a third: "the pain of birth caused by factors from outside". ${ }^{26}$ These diagnoses, in their various versions, apparently originated in Soranus' treatise, and persisted into the late Middle Ages and the Renaissance. ${ }^{27}$

The first prerequisite for "natural birth" is the duration of pregnancy, in which the foetus matures to an extent allowing it to leave the uterus with minimal outside intervention and to remain viable outside the uterus. In ancient Greece and during the Middle Ages, "natural birth" was held to occur "at the end of the seventh month or the ninth or the tenth"; 28 birth in the eighth month of pregnancy was thought to be unnatural, or extremely dangerous to the foetus. This belief can be traced to the treatises of Hippocrates and Aristotle. However, the Hebrew manuscript raises a unique point, in that it gives this belief an explanation founded on astrology. ${ }^{29}$

During the Middle Ages, astrology was considered by the three monotheistic cultures as a pure science. As in other branches of science, astrological works were translated into Arabic in the eighth and ninth centuries, from Persian, Indian, and Greek sources. Both Muslims and Jews wrote treatises on the various aspects of astrology, as an integral part of the intellectual and scientific activity of the early and central Middle Ages. ${ }^{30}$ Starting from the last quarter of the eleventh century, Arabic and Hebrew astrological literature was translated into Latin, where it held a place of importance in Western Christian science until the sixteenth century. ${ }^{31}$ Despite the fact

\footnotetext{
${ }^{26}$ British Library, Montefiore, Ms. 420, ff. 39v. -40 r.

${ }^{27}$ See, for example, the fifteenth-century Medieval woman's guide to health: the first English gynaecological handbook, Middle English text with introduction and modern English translation by Beryl Rowland, London, Croom Helm, 1981, p. 122.

${ }^{28}$ Ms.P, f. 66v., lines 2-3. Cf. Ann Ellis Hanson, 'The eight months' child and the etiquette of birth: Obsit omen!', Bull. Hist. Med., 1987, 61: 589-602.

${ }^{29}$ Hippocrates' arguments are in no way related to astrological calculations, but are based exclusively on a description of foetal motion within the uterus and the mother's diseases: "Pour la naissance à huit mois, je dis qu'il est impossible que les enfants supportent les deux souffrances survenant coup sur coup: c'est la raison pour laquelle les foetus de huit mois ne survivent pas. Il leur arrive en effet coup sur coup de subir la souffrance survenue dans la matrice et celle de l'accouchement: c'est pour cela qu'aucun foetus de huit mois ne survit." 'Du foetus de huit mois', Hippocrate, texte établi et traduit par Robert Joly [et al.], vol. 11, Paris, Belles Lettres, 1970, p. 174. Aristotle is less decisive in this matter: “ . . children are born at seven months and ten months and at intermediate times, and indeed eight months' babies live, though less often than the others", Aristotle, Generation of animals, English translation by Arthur Leslie Peck, second ed., London, Heinemann, 1953, p. 439 (772b).

${ }^{30}$ On Arab pre-Islamic astrological influences on Islam, see: L. Massignon, 'Les infiltrations astrologiques dans la pensée religieuse islamique', Eranos Jb., 1943, 10: 297-303. See also the studies on Mashā Allāh, a Jew converted to Islam, one of the founders of Muslim astrology: David Pingree, 'Historical horoscopes', J. Am. Oriental Soc., 1962, 82: 487-502; E. S. Kennedy and David Pingree, The Astrological History of Mashā Alläh, Cambridge, MA, Harvard University Press, 1971. On astrology and Judaism, see L. Wachter, 'Astrologie und Schicksalglaube im Rabbinischen Judentum', Kairos, Öst. Ges. Religionswiss., 1969, 2: 181-200; and my article: 'Astrologie juive au moyen âge: aspects théoriques et pratiques', Le Moyen Age, 1987, 93, no.3-4: 323-48.

${ }^{31}$ On the transmission of Muslim astrology to the Latin West, see Francis James Carmody, Arabic astronomical and astrological sciences in Latin translation, Berkeley, University of California Press, $1956 ; 0$. Pederson, 'Astronomy', in David C. Lindberg (editor), Science in the Middle Ages, University of Chicago Press, 1978, pp. 305-8.
} 


\section{Ron Barkai}

that the principles of astrology may be considered as challenging the foundations of monotheistic faith - divine omnipotence, man's free will, and thus also the principle of reward and punishment-, few Jewish or Christian scientists of the period took a firm stand against astrology. Of those few, the most conspicuous were Maimonides, in the twelth century, ${ }^{32}$ and Nicole Oresme, in the fourteenth century. ${ }^{33}$

Along with other branches of astrology, the study of medical astrology flourished in the Middle Ages, ${ }^{34}$ serving physicians in two main areas. The first of these was diagnosis: every man or woman was prone to various diseases, according to his or her birth sign, and certain constellations were considered to cause various diseases. ${ }^{35}$ The second was treatment: medical astrology served to determine the most suitable time for the use of each specific curative. ${ }^{36}$ In fact, astrology was included in the curriculum of compulsory studies in several European schools of medicine. ${ }^{37}$

\footnotetext{
${ }^{32}$ Manfred Ullmann concluded that most great doctors of the Islamic classical period followed Ibn Sina's negation of astrology: Islamic Medicine, trans. Jean Watt, Edinburgh, University Press, 1978, p. 114. Nevertheless, some of the distinguished Muslim doctors, among them at-Tabari, Rhazes, and 'Ali ibn Ridwan, accepted medical astrology. Ibid., pp. 111-12. Maimonides totally refuted astrology for both religious and scientific reasons. See A. Marx, 'The correspondence between the Rabbis of southern France and Maimonides about astrology', Union Coll. Annual, 1923, 3: 311-25; Barkai, op. cit., note 30 above.

${ }^{33}$ Oresme's critique of astrology was based mainly on mathematical calculations. See G. W. Coopland, Nicole Oresme and the astrologers: A study of his Livre des divinacions, Liverpool University Press, 1952; J. E. Murdoch and E. D. Sylla 'The science of motion', in Lindberg (ed.), op. cit., note 31 above, pp. 229-30; M. S. Mahoney, 'Mathematics', ibid., pp. 167-9.

${ }^{34}$ The basic ideas of medical astrology originated in classical Greece. See: L. Gil, Therapeia, la medicina popular en el mundo clasico, Madrid, 1967, pp. 403-57. On the principles of this science, see: Marcelino V. Amasuno, Un texto médico-astrológico del siglo XV: 'Eclipse del sol' del licenciado Diego de Torres, Universidad de Salamanca, Edic. del Instituto de Historia de la Medicina Española, 1972, pp. 13-56.

${ }^{35}$ Thus, for example, the twelfth-century Jewish scholar, Abraham ibn 'Ezra, who wrote several important astrological treatises, argued that: '[Saturn], its particular ailments are insanity, imbecility, tremour, hemiplegy, the diseases which result in a loss of speech, leprosy, the sicknesses of the feet ...". Abraham ibn 'Ezra, The beginning of wisdom, an edition of the Hebrew original of 1148, by F. Cantera. An edition of the old French version of 1273, and an English translation, by R. Levy, Baltimore, Johns Hopkins Press, 1939, p. 195.

${ }^{36}$ Abraham bar Hiya, a twelfth-century Jewish astrologer, wrote inter alia on blood-letting: "[People] were afraid to let blood in the time of Mars, and they warned not to let blood in a day governed by Mars...". 'The letter of R. Abrahan bar Hiya ha-Nasi to R. Yehuda son of R. Barzilai on astrology', published in the Hebrew section of Festschrift Adolf Schwartz, Berlin and Vienna, 1917, p. 24.

${ }^{37}$ Evidence of the relationship between medicine and astrology in Latin Europe may be found as early as a ninth-century manuscript which, inter alia, discusses the various subjects which must be studied in preparation for the study of medicine: "He must also know the science of the stars, so as to recognize their rising, setting, and other movements, and the season of the year, since our bodies change along with these, and since human illnesses are affected by their normality and abnormality': L. C. MacKinney, 'Medical ethics and etiquette in the early Middle Ages', Bull. Hist. Med., 1952, 26: 15. The strength of this relationship in the Middle Ages is attested to by a treatise attributed to Hippocrates, translated from the Greek and apparently also from the Arabic by Peter of Abano and William of Moerbeke: "Dixit Ypocras qui fuit medicus et magister optimus, cuius modi medicus est qui astronomiam ignorat, nullus homo debet committere se in manus illius, qui non est medicus perfectus": $\mathrm{L}$. J. Thorndike, 'The three Latin translations of the Psuedo-Hippocratic tractate on astrological medicine', Janus, 1960, 49: 113. Cf. idem, 'Manuscripts of the writings of Peter of Abano', Bull. Hist. Med., 1944, 15: 201-9. On the place given to astrology in the curriculum of the medieval faculties of medicine, see P. Kibre and N. G. Siraisi, 'The institutional setting: the universities', in Lindberg (ed.), op. cit., note 31 above, pp. 135-40.
} 
The theory whereby each month of foetal development is affected by a different planet was mentioned as early as the tenth century, by 'Arib ibn Sa'id. It should, however, be noted that that author mentioned the astrological theory as one of several dealing with foetal development, and that he himself had significant reservations as to its validity. ${ }^{38}$ In brief, 'Arib ibn Sa'id's explanation states that Saturn affects the development of the foetus in its mother's womb during the first month of pregnancy. On completion of the cycle of influence exerted by each planet during a different month of pregnancy, Saturn - whose nature is cold, dry, and noxious-returns to control the eight month. As a result, "the foetus will not move in the womb and will become ill, and if it is born in that month, it will not live.",39

This view was later adopted by Latin writers as well. For example, it appearsadmittedly, with certain modifications - in the work of the Dominican encyclopaedist Vincent de Beauvais (1190-1264). ${ }^{40}$ Even the treatise on the nature of women attributed to Albert the Great, which rejects the commonly held belief that natural birth was possible in the seventh month "because the foetus is still not sufficiently formed and complete", tends to believe that infants born in the eight month, under the influence of Saturn, would be sickly or die. ${ }^{41}$

To this belief, long accepted by medieval astrologers and doctors, the author of the Hebrew treatise under discussion added an interesting comment about foetal movement. On one hand, this quality is a definite sign of foetal viability; on the other, Saturn (according to the treatise) is characterized by immobility, thus preventing foetuses born under its influence from moving. Even if Saturn should move, added the author, such motion would be "against the Supreme Power"42 — that is, the power of the Creator-and thus would not afford the foetus much chance to survive.

The link between astrology and obstetrics in the Middle Ages added a certain theoretical dimension to the latter science. The explanation given by ancient Greek medicine as to the non-viability of an eight-month foetus was based on physiological factors: foetal movement within the uterus, and uterine diseases. The description of

\footnotetext{
${ }^{38}$ In the beginning of this passage, he wrote: "Concerning those who believe in the stars' evidences and in what is told about the stars' government, they claim . . ".: 'Arib ibn Sa'id, Kitäb khalq al-janin, op. cit., note 3 above, pp. 38-9. A similar explanation was given by al-Majūsī, relating to Hippocrates' theory on eight-month foetuses. Cf. Ullmann, op. cit., note 32 above, pp. 112-13. Rhazes, on the other hand, pointed out that birth took place in the seventh or the ninth month, but mentioned neither the "danger" to the newborn in the eight month, nor the astrological theory: Tib ar-Rāzi, op. cit., note 25 above, p. 412.

39 'Arib ibn Sa'id, Kitäb khalq al-janin, op. cit., note 3 above, p. 39.

40 "Habent igitur et septem planetae aliquid in compositione embrij in specie. Saturnus quidem frigidus est et siccus. Sua frigitate primo mense spermati grauitatem, et sui siccitate compaginationem facit .... Ideo octauo Saturnus redit, et certa vice simul infrigidando embryoni et matrici grauitatem infert, sua siccitate humores extenuans, quibus embryoni nutrimentum partus attribuitur, et propter hoc nati in hoc tempore aegrè perdurant ...". Vincent de Beauvais, Bibliotheca mundi, Douai, 1624, vol. I, XV: 49, col. 1121-2.

41 "Item si aliquisper nasceretur in septimo mense, ille moreretur, quia non est adhuc debite formatus et consolidatus ... Et ille Saturnus multum infrigidat et siccat et perconsequens stringit foetum, et ideo aliqui Astronomi ponunt foetum generatum in octavo mense, moribundum vel mortuum esse ... ", Alberti Magni De secretis mulierum, Amsterdam, 1740, p. 40. Compare the following statement by the Jewish astrologer Abraham ibn 'Ezra, whose treatises were popular in Christian Europe and influenced astrological thought until the time of the Renaissance: "Saturn is cold and dry; it is very pernicious; it denotes destruction, ruin, death, affliction, weeping, grief, complaint and ancient things", Beginning of wisdom, op. cit., note 35 above, p. 193.

${ }^{42}$ Ms.P, f. 67r., lines 9-11.
} 


\section{Ron Barkai}

foetal development throughout the months of pregnancy under the influence of the seven planets, and the affinity between the physical condition of the foetus and the "natural" qualities of the planet in question, added a more generalized, cosmological explanation, which apparently also fitted in with the then-prevailing concept of man as microcosmos. ${ }^{43}$ In other words, a medical-astrological theory arose in reference to one of the most important questions dealt with by medieval obstetrics: the desired duration of pregnancy-according to the text, one of the important conditions for "natural birth".

By contrast, modern obstetrical science considers birth in the seventh or tenth month of pregnancy as unnatural. In the seventh month, as defined in a treatise attributed to Albert the Great, the foetus is still not sufficiently mature. On the other hand, by the tenth month, the birth is considered late, and often requires outside intervention by a doctor or midwife. Interestingly, the opinion that birth in the eight month is even more dangerous than in the seventh has remained a popular folk belief to this day. In fact, it may often be found even among midwives and hospital nurses who are unaware of this belief's ancient and medieval origins.

The second prerequisite for "natural birth" is the proper presentation of the foetus in utero. The author of the Hebrew treatise is aware of the fact that vertex presentation is easier to deliver than other presentations, ${ }^{44}$ especially that of persistent occiput posterior, which may be found in some ten per cent of births.

"Unnatural birth", as explained in the treatise, results from pathological presentations which cause complications during parturition. Three of these presentations are concisely described in the text itself, and another sixteen in the drawings appended thereto. Modern obstetrics also considers these to be the principal pathological presentations, and to require some form of medical intervention. The three presentations described in writing are footling breech presentation, compound presentation, and transverse lie. The treatment suggested by the author for these problematic presentations is intervention by the midwife, who should "gently" rotate the foetus, by bringing its arms and legs back into place, until a state of normal labour is achieved ("until [the position] is natural"). ${ }^{45}$

Illustrations similar to the diagrams of the pathological presentations accompanying Ms.P may be found in Latin gynaecological literature, starting with Muscio's treatise. ${ }^{46}$ It may be assumed that such drawings also accompanied Soranus' treatise, which was the source of Muscio's work. Loren MacKinney cites twenty gynaecological manuscripts illustrated by such diagrams. To these may be added several manuscripts not mentioned by that author, bringing the total number close to

\footnotetext{
${ }^{43}$ On the origins of the concept anthröpos mikros kosmos, see: Gil, op. cit., note 34 above, p. 408 . Cf. Vincent de Beauvais, Bibliotheca mundi, op. cit., note 40 above, I: XXX.

${ }^{44}$ A similar description appears in most medieval tracts dealing with birth difficulties. See, e.g., Sorani gynaecia, Rose, op. cit., note 13 above, p. 79; Paul of Aegina, op. cit., note 25 above, p. 194; 'Arib ibn Sa'id, Kitäb khalq al-janin, op. cit., note 3 above, p. 50; Tib ar-Rāzì, op. cit., note 25 above, p. 413; Medieval woman's guide to health, op. cit., note 27 above, p. 122.

${ }^{45}$ Ms.P, f. 66v., lines 31-2.

${ }^{46}$ See the drawings a the end of Rose's edition, op. cit., note 13 above.
} 
twenty-five. ${ }^{47}$ This phenomenon, common in Latin Europe, had-again, to the best of my knowledge - no parallel in Muslim medical literature, and the illustrations appended to Ms.P are the only ones known in Hebrew medical works. They represent sixteen pathological presentations, discussed in a similar manner in several treatises of this kind. However, their artistic style, the structure of the womb, and the detailed drawing of the foetus and especially its hair, are startlingly similar to those found in a thirteenth-century Latin manuscript, in which they are appended to a treatise which begins "Incipit genecea cleopatre ad deosatam . . .". 48 This work has been identified by $\mathrm{J}$. Benton as $U t$ de curis, one of the three treatises included in the work known as Trotula major. ${ }^{49}$ Ten of the illustrations of the Hebrew manuscript (ff. 69v.-70v.; see plates) show the uterine opening facing upward. This is certainly not a binder's error, because on the recto of $f .69$, the uterine openings are drawn facing downward. It seems to me that this resulted from a lack of attention on the part of the illustrator-copier, and has no significance as regards the concept of pathological presentations. It should be emphasized that, while the Latin manuscripts actually use such diagrams to illustrate each pathological presentation described in the text, in the Hebrew manuscript there is no real connection between the text and the diagrams.

The third state described in the treatise is that of "difficult birth". This is characterized by a foetus unable to leave the uterus, and a mother in protracted physical and mental agony ("anguish and ... anxiety"). The difficulties in this state may result from two types of factors: those external, have nothing to do with the process of delivery itself; and the internal, contingent upon the condition of the mother and foetus.

Among the external factors mentioned in the Hebrew treatise are extreme heat or cold. ${ }^{50}$ It was commonly believed in the Middle Ages that intermediate, or moderate, conditions were ideal in almost every context, including that of climate. Accordingly, the author of the work believed that the ideal time for delivery is in the spring, a season milder than either summer or winter. ${ }^{51}$ By contrast, modern obstetrics holds that hot weather accelerates the birth process.

The second external factor is the skill and experience of the midwife herself. An ignorant and inexperienced midwife cannot be effective; when even the slightest complications are present, she may well endanger both mother and baby.

Our knowledge of the delivery procedures used in the Middle Ages, and of the extent of aid administered to labouring women by midwives and doctors, is scanty. Studies

\footnotetext{
${ }^{47}$ L. C. MacKinney, Medical illustrations in medieval manuscripts, London, Wellcome Historical Medical Library, 1965. See the index, s.v. 'foetal presentations'. To these manuscripts, we may add the drawings in the Medieval woman's guide to health, op. cit., note 25 above, pp. 124-33, and in the Flemish treatise Vrouwengeneeskunde in Vlaanderen tijdens de late middeleeuwen, published by Anna Delva, Bruges, Genootschap voor Geschiedenis, 1983. Cf. Kurt Weitzmann, Illustrations in roll and codex: a study of the origin and method of text illustrations, Princeton University Press, 1947, p. 136; Harold Speert, Histoire illustrée de la gynécologie et de l'obstetrique, trans. Suzanne Caton, Paris, Dacosta, 1976, esp. pp. $172-80$ (I was unfortunately unable to consult the original English version).

48 Paris, B.N. Ms. Lat. 7056, ff. 87r.-89r.

49 Benton, op. cit., note 2 above, pp. 33-4.

${ }^{50} \mathrm{Cf}$. Muscio's version: “. . . aut frigore nimio aeris aut paulo plus calido . . ": Sorani gynaecia, op. cit., note 13 above, p. 79.

${ }^{51}$ Ms.P. f. 67r., line 19.
} 
carried out to date in this area have relied on two types of sources, miniature illustrations in manuscripts, and medical and encyclopaedic treatises, each with its own characteristic limitations. The miniatures generally portray the life of the uppermost stratum of medieval society; moreover, and more importantly, they are not so detailed as to enable us to utilize them in a study of the delivery process. Even the medical manuscripts seldom supply detailed descriptions of the different phases of birth, interventions by those surrounding the labouring woman, and the various solutions suggested for difficulties of parturition. ${ }^{52}$ It should also be kept in mind that medieval medical treatises drew much of their information from sources originating in ancient Greece, and we are unable to determine to what extent these sources were actually used in that period as textbooks for the instruction of medical and paramedical staff whose duties included assistance in delivery, and especially for the instruction of midwives. As for the encyclopaedic treatises, the information which they supplied was, by their very nature, concise and abstracted, and they were probably not used to provide more than general knowledge. ${ }^{53}$ Analysis of the miniatures and the written sources reveals that labouring women were customarily assisted by a number of women, at least one of whom was a professional midwife. The intervention of a doctor-usually a man-was sometimes required in cases of severe complications during the birth. ${ }^{54}$ Despite all the reservations expressed above, it should be stressed that several of the written works include descriptions of fifteen or sixteen pathological foetal presentations, accompanied by explanations addressed to the midwife herself, instructing her how to handle these cases in order to deliver the baby "naturally". The question remains as to how many of the midwives actually received this information.

The Hebrew treatise which has come down to us provides very brief information on the qualities required of midwives. This brevity may, perhaps, be ascribed to the concise nature of the work as a whole. More suprising is the fact that 'Arib ibn Sa'id's treatise, devoted in its entirety to the care of pregnant women and the birth process,

\footnotetext{
52 An attempt to use miniatures to recreate the birth process of the Middle Ages may be found in the work by Danièle Alexandre-Bidon and Monique Closson, L'enfant à l'ombre des cathédrales, Lyons, Presses Universitaires de Lyon, Éditions du CNRS, 1985, pp. 53-62. A number of important works describe the birth process in early modern times: Mireille Laget, Naissances, l'accouchement avant l'âge de la clinique, Paris, Éditions de Seuil, 1982; Yvonne Knibiehler and Catherine Fouquet, La femme et les médecins, Paris, Hachette, 1983, pp. 177-84. The article by M. Salvat, 'L'accouchement dans la littérature scientifique médievale', Colloque du Cuerma, L'enfant au moyen âge, Paris, Champion, 1980, pp. 87-106, demonstrates the limitations of modern research in this domain. Cf. Vern L. Bullough, The development of medicine as a profession: the contribution of the medieval university to modern medicine, New York, Hafner, 1966, pp. 82, 101 .

${ }^{53}$ See for example, the following passage from a thirteenth-century work by Bartholomaeus Anglicus: "A midwife is a woman that hath craft or skill to help a woman that travaileth of childe, that she beare and bring forth hir child with the lesse pains and sorrow, and for that the childe should be borne with the less trauayle, she anoynteth and balmeth the mothers wombe, and helpeth and comforteth hir in that wise. Also she taketh the child out of the womb, and knitteth his nauell foure inches long ...": Bartholomaeus Anglicus, De proprietatibus rerum, VI: 11, translated by S. Batman, London, 1582, p. 174. Vincent de Beauvais, who discussed the difficulties of birth and the treatment of the newborn, did not mention the midwife: Bibliotheca mundi, op. cit., note 40 above, I, cols. 2334-5.

${ }^{54}$ MacKinney, in his book, shows a miniature taken from a thirteenth-century manuscript, depicting a woman in the birth process, assisted by four women. He underlines "the absence of any physician". Op. cit., note 47 above, p. 94; fig. 92. In fact, we know of several miniatures depicting the intervention of a male doctor: see, e.g., Alexandre-Bidon and Closson, op. cit., note 52 above, pp. 46, 60 .
} 
devotes little attention to this question, ${ }^{55}$ although it dwells at length on the subject of wet-nurses: their selection, physical qualities, and character. ${ }^{56}$ Detailed descriptions of midwives may be found in medieval treatises directly or indirectly derived from Soranus. ${ }^{57}$ One of the conspicuous qualities required of the midwife, according to that tradition, is that she be litterata (in the Hebrew version: yoda'at sefer); however, although we have some limited information on educated women active in medicine during the Middle Ages, the field of midwifery remains obscured by the mists of time. ${ }^{58}$

The third factor mentioned in Ms. $P$ as an external cause of "difficult birth" is the most interesting and surprising part of the entire text: a suture performed in what the text refers to as the "mother's mouth", which subsequently became rigid to the point of obstructing the foetal passage. ${ }^{59}$ The version presented in Ms. $L$ differs in two major points: (1) the obstructive cause it mentions is a scar, and not a suture; (2) instead of the vague expression "mother's mouth", it uses a clear Hebrew term, rehem (= "uterus"). This version resembles Muscio's Gynaecia, which mentions a cicatrix as one of the possible obstructions to the birth process; ${ }^{60}$ it is even closer to the Hebrew adaptation, Sefer ha-Toledet: "if it [the difficult birth] is caused by things which close the mother's mouth, such as the closing of wounds". ${ }^{61}$

The Hebrew word for "uterus", accepted since Biblical times, is rehem - a cognate of the Arabic rahim; this, in fact, is the term commonly used in most medieval Hebrew

55 "The midwife should be gentle, delicate, equipped with instruments and knowledge, and long experience and practice with women, trained in receiving the newborn. She has to cut her nails before approaching ... ": Kitäb khalq al-janin, op. cit., note 3 above, p. 46.

56 Ibid., pp. 55-7.

57 The following are the characteristics required of a midwife, according to Muscio: "principaliter quae litteras novit et habet ingenium praesens et memoriam, studiosa, munda, in universo iam corpore integra, fortis et laboriosa, .. . femina omnium mulierum causarum docta, etiam medicinali exercitatione perita". He added regarding the best type of midwife: "quae exercitata est medicinalibus actionibus cum prudentia iustissima et commune et quod urget providens et horum diligentiam coniungens, quae [. . .] pore adunatim possit et per partes dividere et accidentia mitigare propter insecutionem causae, non iracunda nec turbulenta, compatiens, solida, pudica, arguta, quieta, prudens, animosa, nec avara.'Sorani gynaecia, op. cit., note 13 above, pp. 5-6. Sefer ha-Toledet, the Hebrew adaptation of Muscio's treatise, adds one more quality: the midwife must be "God-fearing”. British Library, Montefiore Ms. 420, f. 26r.

58 Relatively speaking, a not inconsiderable amount of information has come down to us on educated women active in medicine in Christian society. Concerning the physician Trotula, see the article by Benton, op. cit., note 2 above. Cf. Danielle Jacquart, Le milieu médical en France du XIIe au XVe siècle, Geneva, Droz, 1981, pp. 47-55. See also A. L. Wyman, 'The surgeoness: the female practitioner of surgery 1400-1800', Med. Hist., 1984, 28: 22-41; and, regarding educated Jewish women doctors, Harry Friedenwald, 'Jewish doctoresses in the Middle Ages', Medical Pickwick, 1920, 6; reprinted in his Jews and medicine, op. cit., note 7 above, vol. 1, pp. 217-20. Our information on the reality of Muslim society is more limited. An example of a woman doctor who learned her profession in the framework of the oral tradition handed down throughout her family may be found in the Inquisitional tribunal proceedings of the morisco sanador Roman Ramirez. Ramirez stated that he learned the profession of medicine from his mother, who was conversant in matters of medicine and healing herbs, and was "a very good midwife". She had learned her profession from her father, also a doctor. It turned out, however, that she possessed no medical literature: “. . . su madre, nunca tubo libros de medicina ni escripturas de las medicinas que hazía”. Luis Garcia-Ballester, Los moriscos y la medicina: un capitulo de ía medicina y la ciencia marginadas en la España del siglo XVI, Barcelona, Labor Universitaria, 1984, pp. 148-9.

${ }^{59}$ Ms.P. f. 66v., lines 7-8.

${ }^{60}$ Sorani Gynaecia, op. cit., note 13 above, p. 81 .

${ }^{61}$ British Library, Montefiore, Ms. 420, f. 40r. 
medical treatises. ${ }^{62}$ The terms em (= "mother") and pi ha-em (= "mother's mouth") occur mainly in Hebrew manuscripts translated from Latin or indirectly influenced by Latin texts, in which terms such as matrix, os matricis, and orificium matricis are frequently used. ${ }^{63}$ The problem with these terms is that, in the case of the manuscript under discussion, we are unable to determine whether the reference is to the uterus, cervix uteri, or vaginal opening. ${ }^{64}$ This question is of extreme importance in analysing Ms. $P$, as the procedure of suturing is rarely encountered in the Middle Ages, and the author's meaning in this connection cannot be definitely ascertained. The version appearing in Ms. $L$ is of no help to us, as, although it explicitly discusses the uterus, it does not mention suturing or the removal of sutures by the surgeon. Futhermore, it is unlikely that medieval doctors were capable of such delicate and complex procedures. It is, therefore, still possible that the reference is to a suture of the vagina, which had apparently been lacerated as a result of sexual intercourse at an early age, or by previous parturition. In these cases, subsequent fibrosis of the suture would narrow the vaginal opening. ${ }^{65}$ In any event, whether we admit the first hypothesis, of vaginal sutures, or the second, of the suture of the uterus, the passage in question indubitably constitutes an early and unusual reference to a medical-surgical practice of this type. (It should be noted that gynaecological operations, although known during the Middle Ages, as indicated by descriptions of surgical instruments in az-Zahrāwīs treatise, were performed only rarely. Even Caesarean sections, referred to in some of the treatises, were only performed following the death of the pregnant women, in an attempt to save the foetus.) ${ }^{66}$

The "internal" reasons for difficult birth, as listed by the treatise, stem from the development of the labouring woman and the foetus, including pathological states of one or the other. Modern obstetrics definitely confirms the medival author's finding of

62 This term appears many times in the Bible. See e.g. Genesis 20:18; Exodus 13:15; Numbers 12:12; Job 31:15; Jeremiah 20:18; I Samuel 5:6. For the usage of this term in the Middle Ages, see the commentary on Had al-'Insān, attributed to Sa'adia Gaon, written in Arabic and translated into Hebrew: S. Muntner, 'Rabbenu Saadia's Commentary on "Had el-'Insān" (The Anatomy of Man)', Koroth, 1952, 1: p. 107; and the Hebrew translation of Maimonides' Aphorisms, Jerusalem, Mossad Harav Kook, 1969, p. 207. This rule has some important exceptions, such as the treatise attributed to Abraham ibn 'Ezra. Although of Arabic origin, the treatise makes use of the term em ("mother"), rather than rehem ("uterus"). Sefer ha-Nisyonot, the Book of Medical Experiences attributed to Abraham ibn 'Ezra, edited, translated, and commented by J. O. Leibowitz and S. Marcus, The Magnes Press, The Hebrew University, Jerusalem, 1984, pp. 222-3.

${ }^{63}$ The author of Sefer ha-Toledet identifies the term em with the uterus: "We are accustomed to call the place of the foetus 'mother', and this is correct, because it is the mother of all the offspring of the world, and it was the mother of all life; and the Greeks called it Isteria". British Library, Montefiore, Ms. 420, f. 26v. However, he used the same term to describe other female genital parts. Cf. Muscio's treatise: '[Matrix] principaliter enim tribus nominibus dicta est, primum ab eo quod mulieres partu suo matres efficit. Graece etiam ystera appelatur...' Sorani gynaecia, op. cit., note 6 above, p. 6.

${ }^{64}$ On the vague meanings of these terms in Latin treatises, see Jacquart and Thomasset, op. cit., note 1 above, pp. 27-36.

${ }^{65}$ This hypothesis may be supported to some extent by the passage in Sefer ha-Toledet describing the same surgical intervention, the removal of a cicatrice in order to facilitate the birth process: "If the "mother's mouth' is hard and closed, it should be cut with a scalpel or with another [instrument] according to the surgical art": British Library, Montefiore, Ms. 420, f. $41 \mathrm{v}$.

66 Alexandre-Bidon and Closson, op. cit., note 52 above, pp. 59-60; Speert, op. cit., note 47 above, pp. 296-307; Laget, op. cit., note 52 above, pp. 248-51. 
an increased likelihood of dystocia among very young or very mature mothers. ${ }^{67}$ It is also correct to state, as does the treatise, that especially large or small foetuses often cause dystocia: in the former instance, due to the relative narrowness of the birth passages; and, in the latter, because the foetus is liable to present pathologically. It is interesting to note that, in diagnosing foetal death, the author cites clinical signs of intrauterine septicaemia: fever, appearance of malaise, and a foul odour, apparently caused by rupture and inflammation of the amniotic sac and membranes. ${ }^{68}$

Foetuses with unusually large heads are liable to cause complications in delivery. These may result from cephalopelvic desproportion, or from pathological states of the foetal skull, such as hydrocephaly; both conditions require medical intervention in childbirth. ${ }^{69}$ The Hebrew treatise mentions the possibility of a two-headed foetus, an extremely rare phenomenon. In the Middle Ages, these were considered monsters, formed by supernatural influence rather than natural mutation; ${ }^{70}$ the birth of monsters (and of lepers) was often considered to result from conception during the menstrual period. ${ }^{71}$ The chances for normal vaginal delivery, in the case of a two-headed foetus, are extremely slight.

${ }^{67}$ Other treatises dealing with difficulties of birth note the possiblity of the woman being narrow in build, but do not connect this with her age. See e.g.: Sorani gynaecia, op. cit., note 13 above, p. 76; 'Arib ibn Sa'id, Kitäb khalq al-janin, op. cit., note 3 above, p. 47. Research shows that, in fact, twelfth-century noblewomen tended to marry between the ages of 12 and 16 (see, e.g., D. Herlihy, 'The medieval marriage market', Medieval and Renaissance Stud., 1976, 6: 16-18). Rural women married rather later than did the daughters of the nobility. A study on peasant society in late fourteenth-century England indicates that peasant women married between the ages of 12 and 20 (Z. Razi, Life, marriage and death in a medieval parish: economy, society and demography in Halesowen 1270-1460, Cambridge University Press, 1980, pp. 229-31); in late thirteenth- and early fourteenth-century France, women married between the ages of 14 and 18 (Emmanuel Le Roy Ladurie, Montaillou, village occitan de 1294-1324, Paris, Gallimard, 1975, pp. 276-7).

${ }^{68}$ Most of the Arabic and Latin treatises which I examined do not note such clinical signs. A similar description may be found in Medieval woman's guide to health, op. cit., note 27 above, pp. 134-6. As in the case of the Hebrew treatise under discussion, the great majority of medieval medical treatises discussing difficulties of birth propose "conservative" treatment only in the extraction of dead foetuses-through the use of materia medica to stimulate labour, or manual intervention by the midwife. By contrast, az-Zăhrawi describes in great detail a surgical procedure used following the failure of "conservative" methods: "Consider, and if the foetus present the vertex, then she [the midwife] should fix hooks in its eyes or in the neck or in the mouth or palate or beneath the chin, or the collar-bone, or about the ribs, or beneath the ribs. But if it presents the feet, let hooks be fixed in the pubic region or middle ribs": Albucasis on surgery and instruments, A definitive edition of the Arabic text with English translation and commentary by M. S. Spink and G. L. Lewis, London, Wellcome Institute for the History of Medicine, 1973, p. 476.

${ }^{69}$ For these cases, az-Zahräwi proposed the following intervention: "And if the foetal head be large and it is tightly squeezed in exit, or if there be a collection of fluid in the head [hydrocephalus], you should introduce between your fingers a spike-shaped scalpel and split the head to let the waters out; and you should smash it with the instrument called cephalotribe ... In the same manner, you act if the foetus have a naturally large head ....". Ibid., p. 478.

${ }^{70}$ This medieval belief was also rooted in the writings of Aristotle. See the Generation of animals, op. cit., note 29 above, p. 439-41. Paul of Aegina referred directly to a monster: ". . . aut grandis capitis aut monstruosum ..." ": op. cit., note 25 above, pp. 193-4. Rhazes' version is very similar to the Hebrew text: "If the difficulty is caused by the foetus, it might be because it gets out before the correct time, or because it is too big, or too little, or its head is big, or it is dead, or sick or there are several [foetuses], or it is not according to nature", Tib ar-Rāzì, op. cit., note 25 above, p. 413. Cf. A. Paré, On monsters and marvels, translated with an introduction and notes by Janis L. Pallister, University of Chicago Press, 1982; J. M. Thijessen, 'Twins as monsters: Albertus Magnus' theory of the generation of twins and its philosophical context', Bull. Hist. Med., 1987, 61: 237-46.

${ }^{71}$ The ancient sages of Israel expressed the concept that a woman conceiving during her menstrual period will give birth to a leprous infant (Tanhuma mezora'). Yosef ben Me'ir Zabara gave this belief an 
The belief of the ancient Greek philosophers in the natural superiority of the male, the "perfect being", over the female, was accepted almost unquestioningly by medieval writers. ${ }^{72}$ The male foetus was thought to occupy the right side of the uterus, and mothers of male foetuses were generally believed to appear more healthy than those of females. This belief is reflected in the manuscript, which states that "the male emerges with less anguish than the female", ${ }^{73}$ a statement having absolutely no corroboration in modern science. On the other hand, the author's statement that overweight women are more liable to suffer complications of delivery than thin ones is confirmed by modern obstetrics.

Following the description of the various types of problems liable to cause a difficult birth, the author proposes a series of means to overcome them, at times basing his recommendations on earlier medical authorities. The medical theory subscribed to by the author-and by medieval doctors in general-was the theory of humours. Although he does not explicitly cite this theory, it is implied in his remark on folio 66v., lines 34-5, that, if the difficulty is caused by disease or external factors, these should be treated by their opposites in order to balance them. In other words, diseases were considered as imbalances between the four bodily humours. Treatment, in such cases, consisted of increasing scanty humours and reducing superfluous humours, in order to bring the four into proper proportion, or, as the text puts it, "balance". Blood-letting, a commonly used medieval method of restoring the balance of humours, is not mentioned in this text.

Another type of treatment, having nothing to do with the theory of humours, involves the midwife's intervention in the birth process-specifically, instructions given by the midwife to the labouring women, directing her to take steps to facilitate delivery. Among these steps is the force which she exerts by proper breathing ("she has to breathe forcefully") and manual pressure in the direction of foetal expulsion ("and massage forcefully downward").

Other procedures mentioned in the treatise are also recognized by modern obstetrical science as efficacious, even though most of them are no longer practised today. The midwife, for example, is instructed to cause the labouring woman to sneeze, and to massage her uterus externally. Sneezing increases the intra-abdominal pressure,

explanation based on the classical theory of humours: Sefer Ša 'ašu'im, ed. I. Davidson, Berlin, 1915, p. 173. Muslim authors, such as Rhazes and al-Majūsī, attributed smallpox to impure or "bad" menstrual blood which nourished the foetus in utero. See Ullmann, op. cit., note 32 above, p. 84. Cf. M. Barber, 'Lepers, Jews and Moslems: the plot to overthrow Christiandom in 1321', History, 1981, 46: 13.

72 For the Aristotelian theory, see the Generation of animals, op. cit., note 29 above, p. 766a. Galen's definition is even more trenchant: "Sicut igitur homo animal est omnium perfectissimum, ita in eo ipso rursus vir muliere perfectior . . . ": De usu partium corporis humani XIV: 6; Claudii Galenii opera omnia, repr. Hildesheim, George Olms, vol. 4, p. 161. Cf. Lloyd, op. cit., note 1 above, p. 175-6. On the transmission of these concepts to the Middle Ages, see: Vern L. Bullough, 'Medieval medical and scientific views of women', Viator, 1973, 4: 485-7; Jacquart and Thomasset, op. cit., note 1 above, pp. 16-32.

${ }^{73} \mathrm{See}$, e.g., the following statement by 'Arib ibn Sa'id: "If the pregnant woman feels a stimulus in her right breast, or in the right side of her uterus, there is not doubt that she is carrying male. And if her right breast is larger than the left, there is no doubt that she is carrying him [a male]": Kitäb khalq al-janin, op. cit., note 3 above, p. 25. Nearly identical phrasing occurs in a treatise attributed to Albertus Magnus: " . . si venter tumescit in dextra parte, et rotundatur, signum est masculi ... si dextram mamillam habet grossiorem signum est masculi; si vero sinistram, signum est foemellae", De secretis mulierum, op. cit., note 41 above, pp. 95-6. 
and can therefore be of value in expediting delivery; similarly, external massage of the uterus can stimulate the muscle fibres to contract, thus accelerating the birth process. The medieval author's recommendation that obese women be made to kneel is not customarily practised in modern medicine. It is, nevertheless, a reasonable one: when the woman is in a vertical position, the weight of the foetus and the internal organs contributes to speeding up the delivery. The suggestion that enemas be given to relieve constipation is still implemented today in certain hospitals, which hold that emptying the rectal passage produces a wider birth canal, thus facilitiating the birth process.

As stated above, the midwife plays an important role in this treatise; she is the one principally responsible for assisting the labouring woman. Aside from skill and experience, midwives were expected to have "lean hands and long fingers", to enable them to intervene inside the uterus, especially in cases of pathological presentation. In describing the tearing of the placenta by the midwife, the author almost certainly did not mean to refer to the placenta itself, but to the amniotic membranes, which the midwife was supposed to tear gently with her nails. This can be seen from the phrase which precedes the description: "when the thin membrane will be broken and some water emerges". ${ }^{74}$ Moreover, one can hardly believe that a treatise demonstrating such familiarity with the birth process would suggest a procedure so dangerous as the tearing of the placenta itself. Among the means of assistance offered by the midwife, the author suggests cervical dilation, which would be likely to intensify the contractions.

Medical historians and anthropologists will be especially interested in the fact that this treatise, though belonging to the learned medicine of the Middle Ages, does not recoil from proposing the use of magical means more commonly encountered in popular medicine. ${ }^{75}$ The reference here is not to curative means, but to substances believed to have powers of attraction. These were not placed in contact with the woman's genitalia, but only had to be brought near them in order to accelerate foetal expulsion. Such powers were attributed to agrimony, which the manuscript advises tying to the woman's thigh, with its roots pointing upward. When thus used, the plant was supposedly capable of drawing out the entire contents of the woman's abdomen; accordingly, the author warns that it should be used with caution, so as not to cause a prolapse of the uterus (descensus uteri). ${ }^{76}$ This magical operation is paralleled in

\footnotetext{
${ }^{74}$ Ms.P, f. 66v., line 24. Compare with az-Zahrāwī's instructions: "Then the midwife should take between two fingers a little scalpel and make an incision in the foetal membrane or open it with the fingernail, to allow the contained waters to flow out." On surgery and instruments, op. cit., note 68 above, p. 468.

75 This phenomenon is not exclusive to medieval science and medicine. Lloyd concluded that: "A very considerable body of evidence can be assembled to show how much of science consists in the rationalisation of popular belief. Time and time again Greek scientific writings reflect or are based on traditional ideas, with or without the addition of some kind of explanation or justification." Op. cit., note 1 above, p. 202. On the use of magic in Islamic medicine, see Ullmann, op. cit., note 32 above, pp. 107-11. Cf. Ron Barkai, Science, magic and mythology in the Middle Ages, Jerusalem, Van Leer Institute, 1987, chapter 3: 'New sources for the history of popular medicine in Spain and North Africa (fifteenth and sixteenth centuries)' (in Hebrew).

76 The same tradition appears in the Middle English treatise: "Also take agrimoyne with his roits and lay the rotes toward the marice, and when she childith do it away lest the marice followe," Medieval woman's guide to health, op. cit., note 27 above, p. 122. Compare to the procedure proposed by 'Arib ibn Sa'id, Kitäb khalq al-janin, op. cit., note 3 above, p. 49.
} 
popular medical literature and magical treatises from the medieval period, such as Sefer ha-Segulot, written by 'Abd ar-Rahmān ibn al-Haitham in the tenth century, ${ }^{77}$ and the The book of medical experiences, a twelfth-century work ascribed to Abraham ibn 'Ezra. In the latter work, Galen is said to have propounded acceleration of the birth process by tying saffron alum to the labouring woman's thigh, and by placing a pottery talisman beneath her feet; the two processes were believed to have similar results. ${ }^{78}$ In the earliest known manuscript of the Jewish magical treatise The [magical] use of Psalms, written in the fourteenth century, as well as in later versions of that treatise, mention is made of pottery talismans placed on the abdomen of a labouring woman. Here, too, the author added a warning that the talisman should be removed immediately after the delivery, so as not to draw out the woman's intestines following expulsion of the foetus. ${ }^{79}$

The second magical means proposed to speed up the birth process involves the use of an apple-shaped vessel filled with various aromatic herbs. Labouring women holding such vessels in their hands were supposed to be strengthened by them, and thus stand the strain of delivery more easily. Another use for the same "apple" is attributed by the medieval author to the Muslim physician az-Zahrāwi: when hung around the woman's neck, its magical powers were supposed to drive the placenta out of her body.

Another method, considered in medieval thought as bordering between science and magic, is the use of special types of stones. This was a very common therapeutic practice in medieval medicine, especially in gynaecology. Such stones were used to assist women who conceived with difficulty, to prevent premature birth, to accelerate and facilitate the birth process, and as abortifacients and contraceptives. ${ }^{80}$ The forces of attraction displayed by magnets were believed by scholars of the Middle Ages to be capable of drawing the foetus out of the mother's womb. ${ }^{81}$

\footnotetext{
77 'Abd ar-Raḥmān ibn Ishaq al-Haitham (d. c. 951) wrote his treatise in Arabic. Unfortunately, the original work has been lost, and we have only its Hebrew translation. This translation was the basis of the treatise attributed to Abraham ibn 'Ezra. Both treatises were published by Leibowitz and Marcus, in Sefer ha-Nisyonot, op. cit., note 26 above.

${ }^{78}$ For al-Haitham's version, see: ibid., pp. 315-16. The author of Sefer ha-Nisyonot attributed this magical treatment to the Greek medical tradition: "Said Galen: if saffron alum is applied to the hip of a woman, this will quicken the birth. He said: take a new potsherd, which has not been touched by water from the day it was made, and draw on it this pattern which I am going to draw, and write on it the calculation which adds up to fifteen . ... Then put the potsherd under the soles of her feet and she will immediately give birth; once she has given birth it must be removed from under her immediately'. Ibid., pp. 239, 241.

${ }^{79}$ New York, Rabbinical College Library, Ms. 1878/21, f. 80v.; and London, Wellcome Institute, Ms. Heb. A 34, f. 7.

80 J. H. Nunemaker, 'Obstetrical and genito-urinary remedies of thirteenth-century Spain', Bull. Hist. Med., 1944, 15: 162-79; Alfonso X, Lapidario (según el manuscrito escurialense H. I. 15), Introducción, edición, notas y vocabulario de S.R.M. Montalvo, Madrid, Gredos, 1981, pp. 24, 35, 36, 184.

81 'Arib ibn Sa'id cited the same magical procedure in the name of Hippocrates. In the same period, al-Haitham proposed: "If [a pregnant woman] holds a magnet in her right hand . . . during the birth, she will give birth quickly." Sefer ha-Segulot (Book of [magical] properties), in Leibowitz and Marcus (eds.), op. cit., note 62 above, p. 316. This tradition was copied by Abraham ibn 'Ezra: "And al-Tabari said: if a woman carries a magnet which attracts iron in her hand, that will quicken the birth; I tested this and found it true." Sefer ha-Nisyonot, op. cit., note 62 above, p. 241. Cf. Ullmann, op. cit., note 32 above, pp. 110-11. In a book on the properties of stones, composed in the court of Alfonso $\mathbf{X}$ in the thirteenth century, appear several gynaecological treatments, in which the properties of various stones are said, inter alia, to ease the birth process: "De los XXVI grados del signo de Aries es la piedra que dizen abyetitiz, que quiere dezir boytrenna. Et este nombre a por que la trae la fumbra del boytre a so nido por que para mas de ligera mente sus fiios ....
} 
The fact that, during the Middle Ages and the Renaissance, simultaneous use was made (especially in medicine) of means and methods then believed scientific and of magical techniques is hardly remarkable. It must be recalled that, to the medieval mind, these two methods were neither opposed to nor even estranged from each other. Magic, medical astrology, and alchemy were held to be equally relevant and necessary branches of knowledge and science, for the benefit of humankind. ${ }^{82}$ An excellent definition of that situation has, in fact, been given by a historian of medieval science: "In the medieval mind, the science of magic lay close to the magic of science." ${ }^{\circ 3}$ The truth of this statement is admirably borne out by the Hebrew treatise On difficulties of birth.

Comparison of the chapter on difficulties of birth in Ms. $L$ with the parallel section in Ms. $P$ shows that both had a more ancient Hebrew source. This may be seen not only from the changes in phrasing, but from the obvious differences in content between the two manuscripts. The theoretical concepts and practical treatments described in this treatise reveal that the author drew his medical views and knowledge from varied sources, both Arabic and Greek, although it is almost certain that the Latin sources reached him in Arabic translation. Thus, for example, in the description of the three types of births (natural, unnatural, and difficult), a striking similarity exists between the Hebrew treatise and Muscio's work; the astrological theory of foetal development and the death of infants born in the eighth month, expressed with reservations by 'Arib ibn Sa id but with confidence by al-Majūsī, repeated in similar terms in the Hebrew text; the description of difficulties of birth casued by foetal presentation, as it appears in the Hebrew work, is similar to that in Rhazes' book, Kitäb al-Hawi. At the same time, it should be stressed that, despite the similarities noted between the Hebrew treatise and any other work-Arabic, Greek, or Latin-we cannot definitively indicate direct copying, as it is quite possible that the information reached the Hebrew author second-hand.

Examination of the terms used for materia medica, and of the linguistic sources of those terms, admittedly reinforces the conclusion concerning the variety of sources on which the Hebrew work is based. Nevertheless, in view of the significantly large number of terms of Arabic and Spanish origin, it may be deduced that the author was a Spanish Jew or of Spanish descent. Additional corroboration of this theory may be found in the fact that the only medical authority cited in the section common to both manuscripts, Hippocrates, is referred to by the Arabic form of his name, Abuqrat-an appellation commonly used among the Jews of Spain. On the other hand, the author of the addendum to Ms.P severely misspelled the names of Muslim doctors mentioned in that section. This leads to the deduction that he may well have been a Jew, more conversant with Latin medical literature, and that he apparently copied the sixteen drawings of pathological foetal presentations from a Latin treatise.

\footnotetext{
Et esta piedra a tal urtud que quanto la meten en cuero de cieruo, et la atan a la mugier a la coxa siniestra, quando esta de parto, pare luego ligeramiente et sin peligro . . .". Lapidario, op. cit., note 80 above, p. 35. Cf. Nunemaker, op. cit., note 80 above, pp. 162-79.

${ }^{82}$ For an analysis of the relationship between science and magic in the Middle Ages, see B. Hansen, 'Science and magic', in Lindberg (ed.), op. cit., note 31 above, pp. 485-506.

${ }^{83}$ Charles Homer Haskins, Studies in the history of medieval science, Cambridge, MA, Harvard University Press, 1927, p. 19.
} 


\section{Ron Barkai}

We may then state that the treatise under discussion exhibits an extremely interesting phenomenon: the confluence of Eastern and Western medical traditions in a single Hebrew work. The treatise was part of the trend, prevalent among the Jews of Spain, Italy, and France, to generate medical literature in the Hebrew language. Examination of Ms. $L$, which, as stated above, includes additional chapters besides that dealing with difficulties of birth, indicates that the treatise in its entirety may have served as a medical handbook, for the author contented himself with brief theoretical explanations, and concentrated primarily on the practical aspects of medical treatment. Naturally, like any medical treatise written at that time, the work at hand was primarily addressed to male doctors; however, it may be assumed that some women also made use of it in their study of obstetrics, either directly, or via a doctor who read to them the chapters required by midwives.

I would like to thank the Van Leer Institute, Jerusalem, for the grant which allowed me to work in the libraries in Paris and London while preparing this article. I also thank Dr Dan Peleg, Department of Obstetrics and Gynaecology, Hasharon Hospital, Petach Tikva, Israel, for his assistance with and comments on this article from the standpoint of modern obstetrics; and Mr Michel Garel, curator of Hebrew manuscripts at the Bibliothèque Nationale in Paris, for his great assistance during my work in that department, and for his professional counsel. 


\author{
APPENDIX \\ On Difficulties of Birth \\ Paris, Bibliothèque Nationale, Ms. héb. 1120 \\ ff. $66 \mathrm{v} .-67 \mathrm{r}$. (fourteenth-century).
}

Note: I have, as far as possible, given the names of the materia medica in English. However, due to the importance of the terminology used by the author, I have included a transliteration of these terms in the notes, preceding each transliterated term with the designation "Hebrew".

f. $66 v$.

1 ON DIFFICULTIES OF BIRTH. The birth [can be] natural, unnatural, or difficult-and for that reason it is especially worthwhile / to examine the natural. ${ }^{84}$ The natural birth [occurs] most at the end of the seventh month or the ninth / or the tenth. ${ }^{85}$ And the head should emerge first with the face downwards, and afterwards the neck, and after that / the shoulder, and it should be that his hands will be alongside [the body]. The unnatural birth [occurs] when the legs emerge /

5 first, or the hands, or the sides. The difficult birth [is] when the foetus cannot emerge and tortures the mother and oppresses her-she will stand / that anguish ${ }^{86}$ and that anxiety ${ }^{87}$ for a long time ... THE REASON for anguished ${ }^{88}$ birth may be external / or internal. The external reason may be extreme heat or extreme cold, or when the midwife is not wise, ${ }^{89}$ or when the uterus $^{90}$ / has been severely injured in its opening and was stitched up ${ }^{91}$ so that when the birth time arrived it could not widen. Or when the birth occurs at an / unnatural time ${ }^{92}$ or when the mother suffers certain diseases in the abdomen. Or when she is very restrained. ${ }^{93}$ And if it is from internal reasons /

10 it may be because the girl ${ }^{94}$ became pregnant before she had her signs [of maturity] and her ways are narrow. Or when she is fat and the opening of the uterus / is closed, or when the woman is spoiled and damaged, or when the foetus is very big and gross, or when he is thin and feeble / and he cannot help himself. Or when the foetus is dead, or when his head is very big, or when he has two heads, or when there are / twins, or when the birth is unnatural, or when it occurs before time, or when the woman is very old, or as a result of the uterus' diseases, / or when the uterus is little by nature and shrivelled, or the uterus is dry and empty of beneficent moisture ... THE SIGNS. If his mother is /

15 strong, and the external reasons and the other well-known [reasons] will be shown [as not being the cause of a difficult labour], then it is a sign that / the birth difficulty is caused by the placenta. And if it is due to the dying foetus, then [the signs] are severe pains around the navel, and slight fever, / and a horrible expression, and a stinking smell, and stinking vapours rising, and the abdomen does not move, and the insomnia, / and the other [signs]; all of them can be recognized from the patient's words . . . ANTICIPATION of diagnosis. When the pains are going downward and the breathing / is regular, the birth will be easy. The male emerges with less anguish than the female; fat women suffer more

${ }^{84}$ Ms. $L$ : "Our intention is especially to discuss the difficult birth".

${ }^{85}$ Ms. $L$ : "or the eleventh".

${ }^{86}$ The author used a Hebrew word equivalent to the Latin angustia, which appears in most Latin texts on difficulties of birth: see e.g. Muscio's Gynaecia, op. cit., note 13 above, p. 81 . The same word occurs in Biblical Hebrew, e.g. Genesis 3:16.

${ }^{87}$ Ms. $L$ : "and she will cry".

${ }^{88}$ Ms.L: "and distressed".

${ }^{89}$ Ms. $L$ : "or when the midwife is not accustomed or [she is] wrongful".

${ }^{90}$ Ms.P: gives the Hebrew word em ("mother"); Ms.L: gives rehem ("uterus"). Cf. the discussion above.

${ }_{91}$ Ms. $L$ : "when there is [in the uterus] cicatrice or hardness".

92 Ms. $L$ : "before the natural time".

${ }^{93}$ Ms.L: "to mean quštipa . . $n$ [constipatio?]".

${ }^{94}$ Ms. $L$ : "the woman". 


\section{Ron Barkai}

20 during the birth than thin ones ... THE CURE OR CORRECTION. When the birth time is approaching, the woman will have a bath in water with Indian aloe-tree, ${ }^{95} \mathrm{bish},{ }^{96}$ aloe, sweet-violet, ${ }^{97}$ camomile, ${ }^{98}$ melilot, ${ }^{99}$ and after that will be anointed with sesame oil ${ }^{100} /$ and sweet almond oil ${ }^{101}$ and hen's suet, ${ }^{102}$ and after that she will descend to a bath place, ${ }^{103}$ and when the birth time will be closer, she will eat / little food but of good quality, such as fat hen soup, and will drink the fragrant wine. And after that, when it [the birth] will be closer, / and the thin membrane ${ }^{104}$ will be broken and some water emerges, she has to breathe forcefully and to massage forcefully /

25 downwards, because this kind of pressing is very helpful, and so a midwife must be chosen with lean hands and long fingers; / and she will open the uterine opening, ${ }^{105}$ and when she sees the placenta, she has to tear it gently with her nails, and to put some suppositories with which to facilitate / the birth [without] fear of abortion. ${ }^{106}$ Take suint, ${ }^{107}$ lily ${ }^{108}$ root, marjoram, ${ }^{109}$ calamint, $^{110}$ two ounces ${ }^{111}$ of each one, and one ounce terebinth, ${ }^{112} /$ pound

${ }^{95}$ Hebrew: alova; Arabic: aluwwa, called also 'ud; Aquilaria agallochum, Lat. Cf. Maimonides, Kitä šarh asmä' al-'uqqar, L'explication des noms de drogues - un glossaire de matière médicale composé par Maimonide; edition and French translation by Max Meyerhof, Cairo, Institut français d'archéologie orientale, 1940, (no. 296); English translation by Fred Rosner, (editor), Moses Maimonides' glossary of drug names, translated from Max Meyerhof's French edition, Philadelphia, American Philosophical Society, 1979. The treatise was translated into Hebrew by S. Muntner, Jerusalem, 1969. See also Ahmad Issa, Dictionnaire de noms des plantes en latin, français, anglais et arabe, Cairo, Ministère de l'Instruction publique, 1930, p. 10, no. 10.

${ }^{96}$ Hebrew: biš; derived from the Persian jundūr al-biš; Aconitum ferox, Lat. Cf. Tuhfat al-Ahbäb, Glossaire de la matière médicale marocaine, texte publié pour la première fois avec traduction, notes critiques et index par H. P. J. Renaud and Georges S. Colin, Paris, P. Guethner, 1934, no. 78; Issa, op. cit., note 95 above, p. 4, no. 14.

${ }_{97}$ Hebrew: violiš. Of the Violacaea family, the plant most commonly used for medicinal purposes in the Middle Ages was the Viola odorata, Lat.

${ }_{98}$ Hebrew: qamamila; Greek: khamaïmelon. Maimonides mentions the Greek name as a synonym for the Arabic bäbünaj; Anthemis nobilis, Lat. Op. cit., note 95 above, no. 39.

${ }_{99}$ Medieval herbalists mention two species of melilot. The more common one is the Melilotus officinalis, Lat., called 'iklil al-malik ("royal crown") in Arabic. The second one, Coronilla scorpioides, Lat., is called 'iklil al-malik al-mu'aqrab ("scorpioid melilot") in Arabic. As the former has been frequently used as an aromatic for medical treatment, I assume that the author refers to this species. Cf. Maimonides, op. cit., note 95 above, no. 128; Tuhfat al-Ahbäb, op. cit., note 96 above, no. 4.

${ }^{100}$ According to Maimonides, "It is the oil of non-decorticated sesame; the oil of decorticated sesame is known by the [Arabic] name siraj". Op. cit., note 95 above, no. 100.

101 Oil made of the fruit of Prunus amygdalus, Lat.

${ }_{102}$ Ms.P gives šun, which has no meaning. Ms. $L$ gives šuman ("suet").

103 Ms. $L$ does not mention the bath.

104 Ms. $L$ : "the first membrane".

105 In both manuscripts appears the Hebrew expression pi ha-em ("mother's mouth").

106 Ms. $P$ gives "fear of abortion", which makes no sense in this context. Ms. $L$ gives the correct reading: "without fear...".

${ }^{107}$ Ms.P: izopi; Ms.L: išof; Greek: hyssopos. The word was assimilated into the Arabic az-züfa and the Spanish ysopo and isopo; Hyssopus officinalis, Lat. Cf. Maimonides, op. cit., note 95 above, n. 136; Issa, op. cit., note 95 above, p. 97 , no. 10.

${ }^{108}$ It is not clear whether the author refers to the white lily, Lilium candidum, Lat., or to the blue one, Iris florentina, Lat. The origin of the name is Greek: leirion. It seems that the form appearing in the text (lili) is a transliteration from the Spanish lilio.

${ }^{109}$ Hebrew: origānī; Orignaum, Lat. For the various species of this family, see Maimonides, op. cit., note 95 above, nos. 235, 236, 242, 309; Issa, op. cit., note 95 above, pp. 129-30.

${ }_{110}$ Hebrew: qalaminti. Maimonides gives the Castillian name qälamānta (calamento) as synonymous to the Arabic Nammam. Like the Arab herbalists, he confused the various species of labiats and mints. Op. cit., note 95 above, no. 225. F. Simonet, in his Glosario de voces ibericas y latinas usadas entre los mozárabes, Madrid, Establicimiento tipográfico de fortanet, 1889, identified the calamento as Melissa calaminta, Lat. (p. 73). Cf. Sefer ha-Nisyonot, op. cit., note 62 above, p. 226.

iil One ounce $=$ approximately 31 grams.

112 Hebrew: terebentina; Spanish: trebentina and trementina. This is a perfumed juice, made mostly of pine. Cf. A. Chirino, Menor daño de la medicina, edición critica y glosario de M. T. Herrera, Universidad de Salamanca, 1973, pp. 117, 120, 195. 


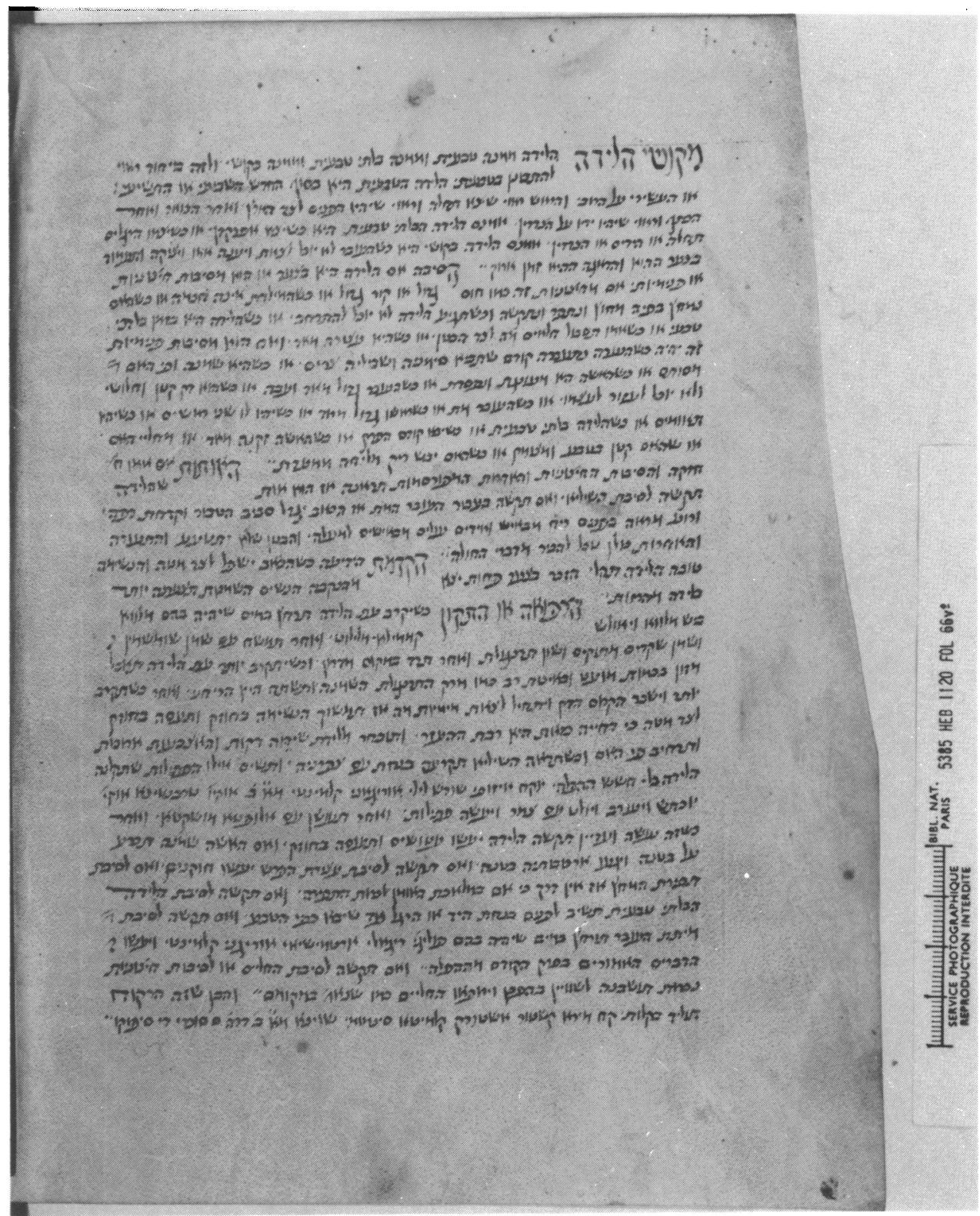

Plate 1. Paris, Bibliothèque Nationale. Ms. héb. 1120, f. 66v. Note: the photographs of this manuscript are reproduced with the permission of the Bibliothèque Nationale. 


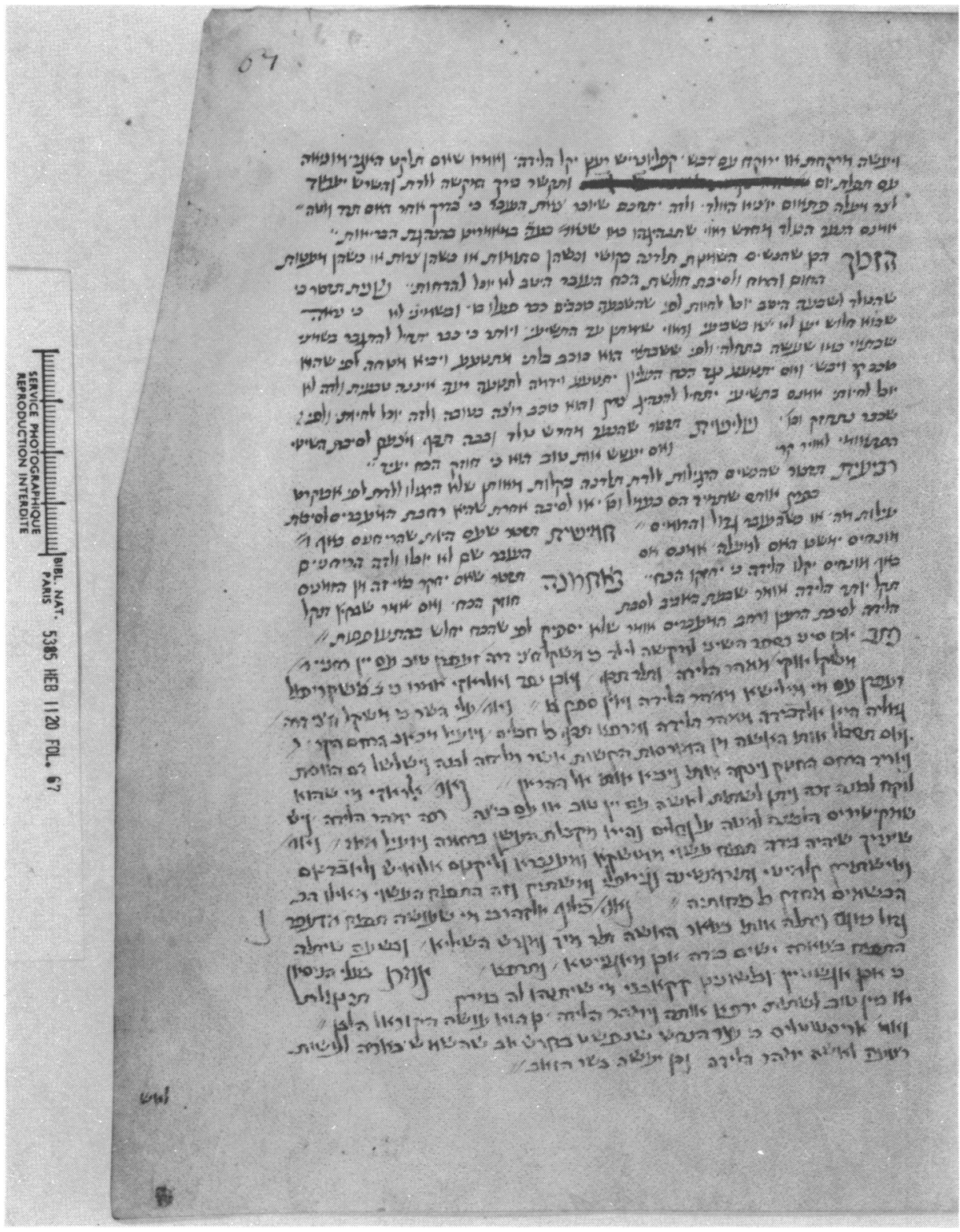

Plate 2. Paris, Bibliothèque Nationale. Ms. héb. 1120 , f. 67 r. 

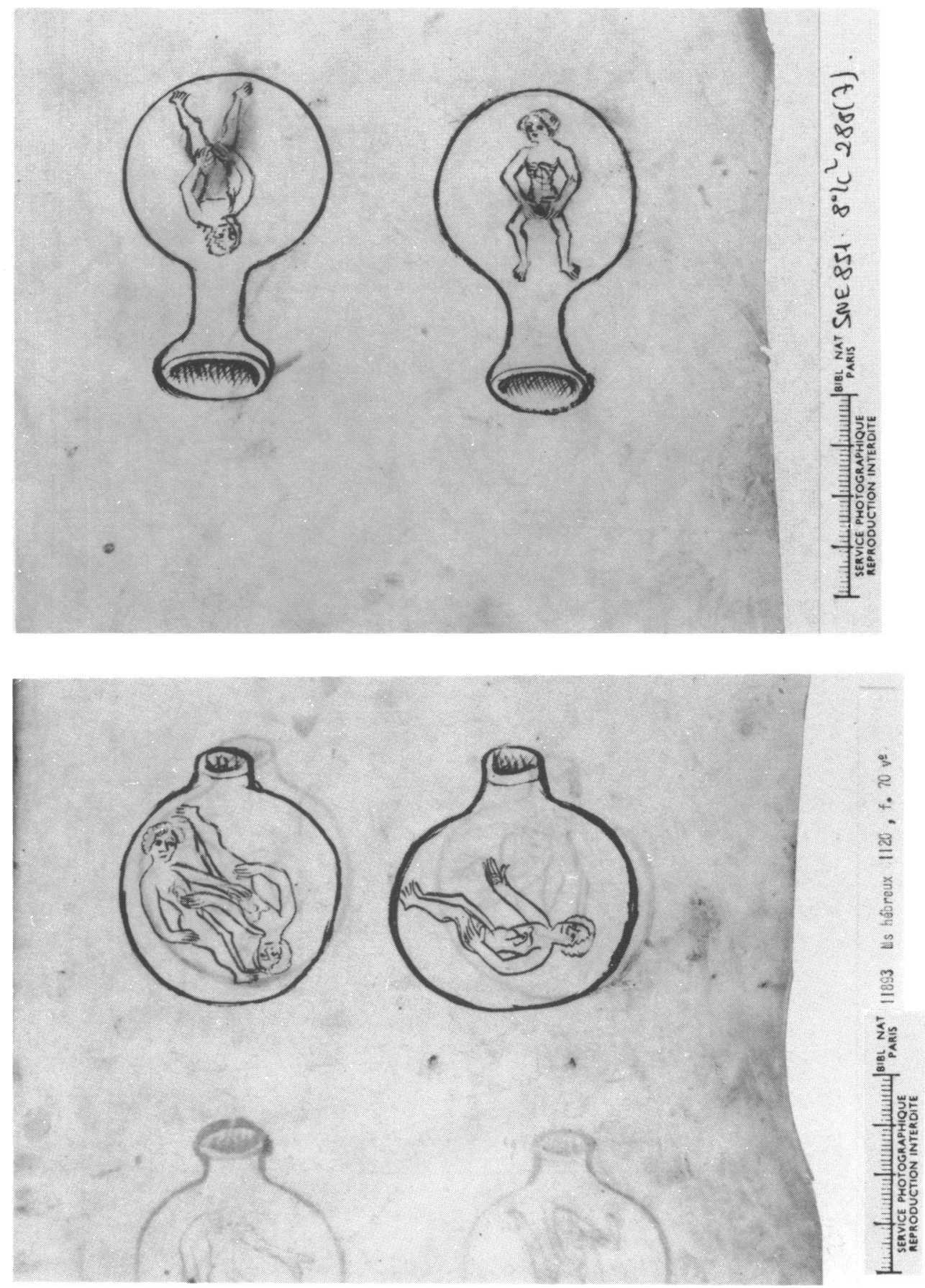

Plate 3. Paris, Bibliothèque Nationale. Ms. héb. 1120 (top) f. 68v. detail, (bottom) f. 70v. detail. 


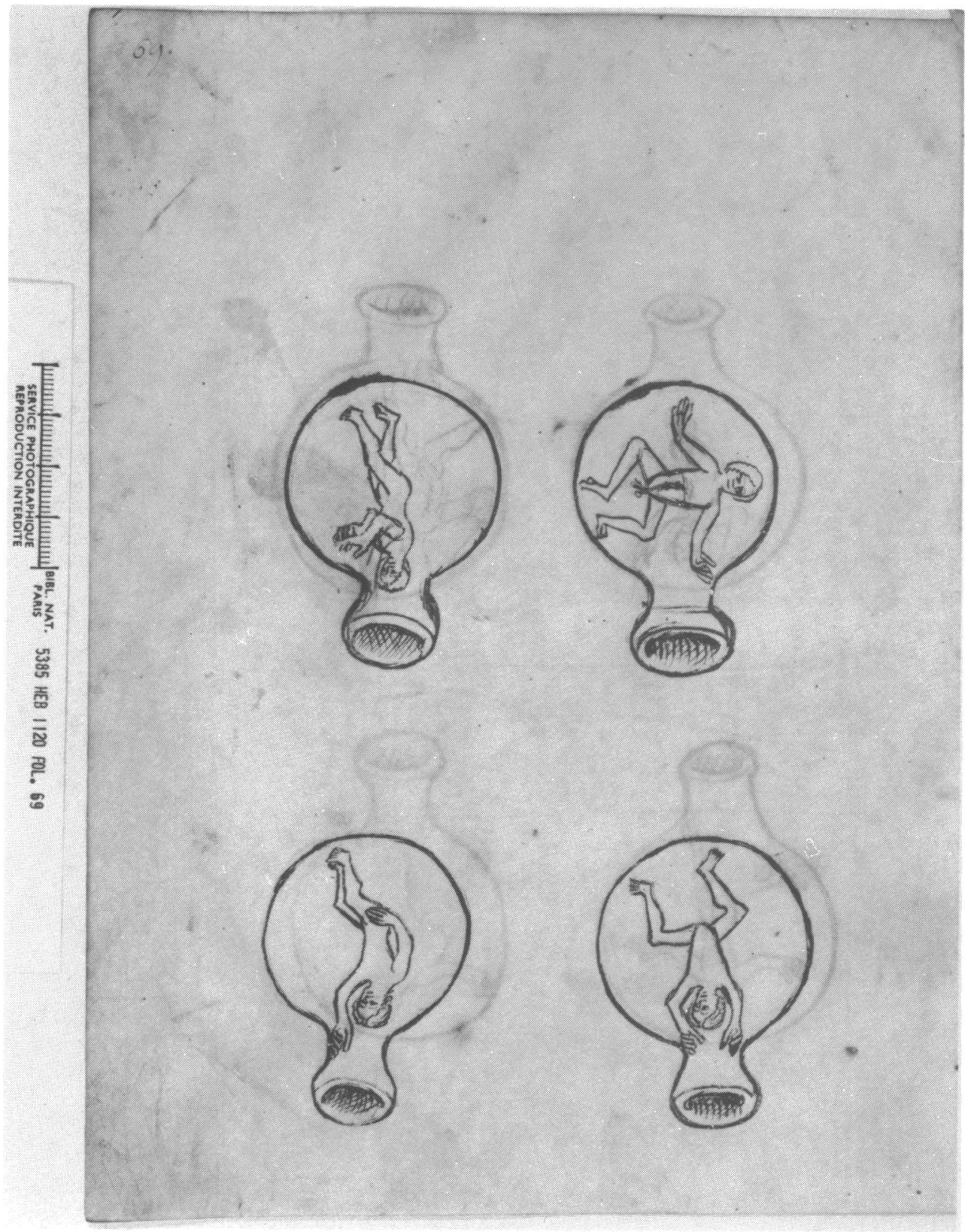

Plate 4. Paris, Bibliothèque Nationale. Ms. héb. 1120, f. 69r. 


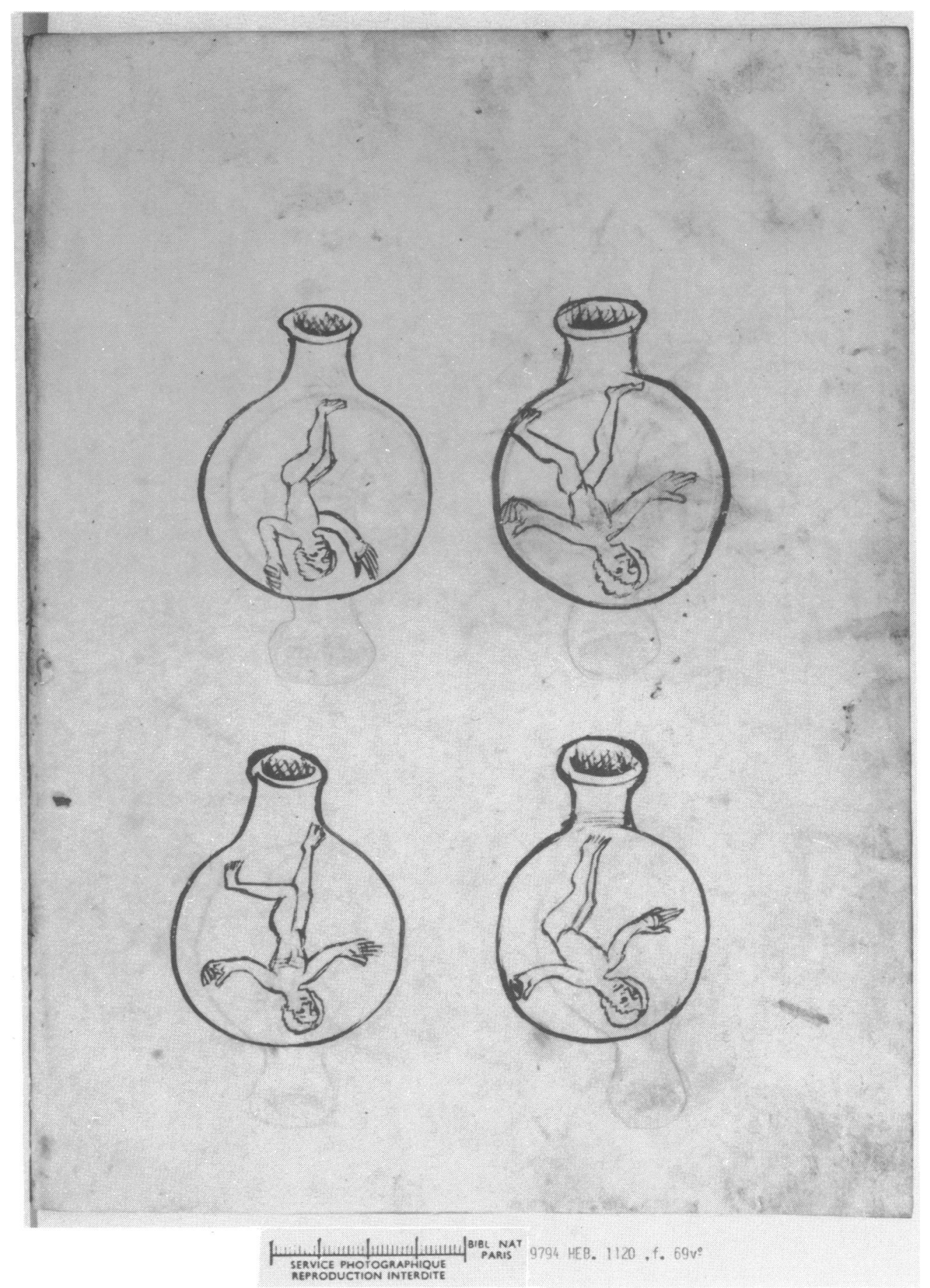

Plate 5. Paris, Bibliothèque Nationale. Ms. héb. 1120, f. 69v. 


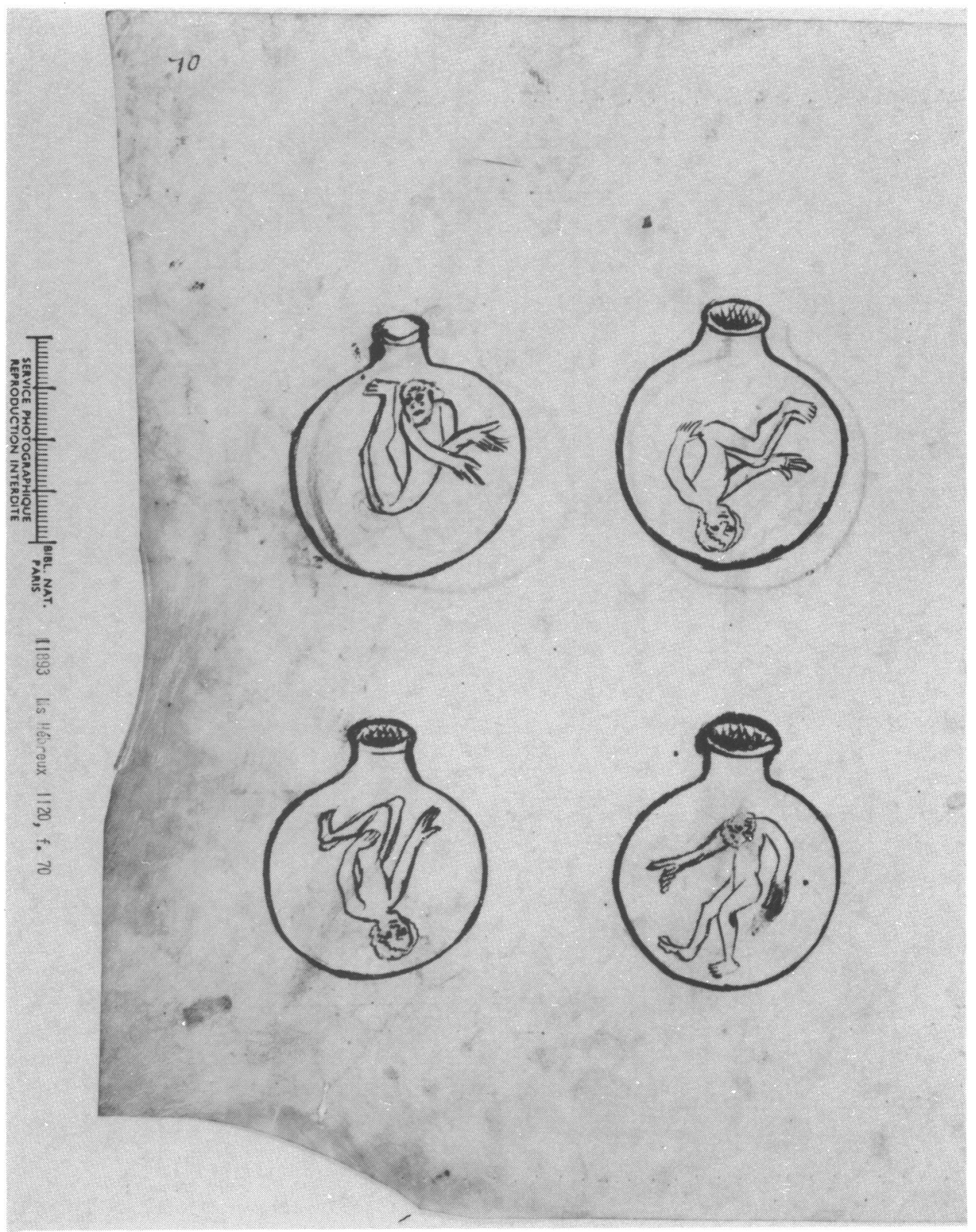

Plate 6. Paris, Bibliothèque Nationale. Ms. héb. 1120, f. 70r. 
and mix [them] and wrap it up with wool [so to] make suppositories. And then she will be fumigated with cuckoopint, ${ }^{113}$ nutmeg; ${ }^{114}$ and then / if all this has been done and still the birth is difficult, make her sneeze and be massaged forcefully. And if the woman is fat, she will kneel /

30 on her belly so that her knees touch her belly. And if the difficulty is caused by constipation of excrement, give her enemas, and if the reason is / the stitching of the injury, there is no way other than to have the surgeon to cut it. And if the difficulty is caused by / unnatural birth, bring the hand or leg back gently until [the position] is natural. And if the difficulty is caused by / the death of the foetus, ${ }^{115}$ [the woman] should wash in water with pennyroyal, ${ }^{116}$ wormwood, ${ }^{117}$ marjoram, calamint, and should undergo / the procedures mentioned in the above chapter on abortion ... And if the reason for difficulty is diseases [of the mother] or clearly external reasons, /

35 these will be balanced by their opposites, as it has been mentioned above. And understand that [with] THIS COMPOUND MEDICINE / she will give birth easily. Take myrrh, ${ }^{118}$ castor, ${ }^{119}$ storax, ${ }^{120}$ calamintha, ${ }^{121}$ cinnamon, ${ }^{122}$ sabin, ${ }^{123}$ two dirhams of each, and with sufficent sugar,

f. $67 r$.

1 and a mixture will be made of them, or they will be mixed with fresh maidenhair ${ }^{124}$ honey, [which] will facilitate the birth. And they said that if agrimony ${ }^{125}$ is collected / at [the time of] the morning prayer ${ }^{126}[\ldots]^{127}$ and tied to the hip of a woman in difficult labour, and the root stands / upwards, suddenly it will expel the baby. And be careful [when you use it] when the

113 Hebrew: alufta; Arabic: al-luf; Arum italicum, Lat. Cf. Maimonides, op. cit., note 95 above, no. 209; Tuhfat al-Ahbäb, op. cit., note 96 above, no. 237.

${ }_{114}$ Ms.P: mušqatä; Ms.L: mušqada. The same form appears in Sefer ha-Nisyonot, op. cit., note 62 above, p. 226. It is the fruit of Myristica fragrans, Lat.

115 Ms. L: " . . . is caused by the foetus".

116 Hebrew: poligi rigäli. The same form appears in Sefer ha-Nisyonot, op. cit., note 62 above, p. 224. Maimonides mentioned the Spanish name bulayu (poleo) as one of the species belonging to the fawdanaj family: op. cit., note 95 above, no. 309. As the Spanish name indicates, it is the Mentha puligium, Lat. Cf. Tuhfat al-Aḥăb, op. cit., note 96 above, nos. 325, 330, 378; Issa, op. cit., note 95 above, p. 117, no. 13.

${ }^{117}$ Hebrew: arțamiši $i$. This plant does not appear in Ms.L. Mamonides gives the Greek name artemisia as synonymous with the Arabic barijasif; Artemisia vulgaris, Lat. Op. cit., note 95 above, no. 63.

118 Hebrew: mira. The same form appears in Sefer ha-Nisyonot, op. cit., note 62 above, p. 226, as efficacious in pregnancy. This is the Commiphora myrrha, Lat. Cf. Issa, op. cit., note 95 above, p. 55 , no. 6.

119 Hebrew: qaštor. A similar form, qastūra, appears in Maimonides' glosssary, op. cit., note 95 above, no. 79. Medieval pharmaceutical literature frequently described the medical uses of the testicles of Castoreum, Lat., especially for gynaecological problems. According to Meyerhof, "the drug is not the testicle, but a desiccated excretion of the glands of genital apparatus of the Castor fiber, L." It is also mentioned in Sefer ha-Nisyonot, op. cit., note 62 above, as an efficacious remedy for gynaecological diseases (pp. 224, 234).

${ }^{120}$ Hebrew: ašturq; derived from the Arabic isturk and isturak. Maimonides distinguishes between the "dry storax" (mai 'a jamida) and the "liquid" one (mai 'a sa'ila). According to Meyerhof, the former is made of Styrax officinalis, Lat., and the latter is a "resinous balsamic juice of Liquidamber orientalis", Lat. Op. cit., note 95 above, no. 228. Cf. Tuhfat al-Ahbäb, op. cit., note 96 above, nos. 58, 239.

${ }^{121}$ See Sefer ha-Nisyonot, op. cit., note 62 above, p. 226.

122 Hebrew: sinamomi; Cinnamonum, Lat. On the different species of cinnamon, see: Maimonides, op. cit., note 95 above, no. 95 .

${ }^{123}$ Hebrew: savina; Arabic: sabina; Junipera sabina, Lat. Cf. Maimonides, ibid., no. 22; Simonet, op. cit., note 110 above, p. 572; Tuhfat al-Ahbāb, op. cit., note 62 above, no. 26.

124 Hebrew: kaplionaris; derived from the Latin Capillum veneris. Cf. Kroner, op. cit., note 7 above, p. 48.

125 Argrimonia eupatoria, Lat. Cf. Maimonides, op. cit., note 95 above, no. 403.

${ }^{126}$ Ms. L: "he should pray while collecting it".

127 Three words censored with black ink. 


\section{Ron Barkai}

foetus emerges, because otherwise it can cause the uterus to descend. / Indeed, the newborn baby deserves the treatment as we will describe, with God's help, in our chapter regimen sanitatis.../

5 THE TIME. Understand that fat women give birth with difficulty, and when they are closed, or when they are narrow, or when they lack / heat and spirit, and as a result of feebleness, the foetus cannot be pushed [out]. SECONDLY, remember that / the [child] born in the seventh [month] is perfectly able to live, as the seven planets have already acted [in his formation]; and in the eighth, he cannot, because we will see / that he is weak, as he did not emerge in the seventh, and he had better wait for the ninth or more, for already Saturn begins to overcome / as he did in the beginning [of the pregnancy]. And as Saturn is an immobile star and inflicts immobility, as it is /

10 cold and dry. And even if it moves, its movement is against the Supreme Power and is like wicked movement, [which] is not natural, and for this reason / [the baby] could not live. But in the ninth, Jupiter ${ }^{128}$ begins to govern, and it is a star that desires good, so [the baby] could live, for / already he has been strengthened etc. THIRD, remember that the newborn baby cries immediately and shouts because of the immediate change / [in being exposed] to cold air. And if he sneezes, it is a good sign, because it proves strength . . . FOURTH, remember that multipara women will give birth more easily than primipara women; ${ }^{129}$ [it is] according to Hippocrates, /

15 in the chapter 'Those who are always in labour', ${ }^{130}$ etc., or for another reason, when she has wide passages for different / reasons, or when the foetus is big or for [other] similar [reasons]. FIFTH, remember that when aromatic [herbs] are put in the nose, / they will attract the uterus upwards, but if the foetus is there, they could not, and for this reason, the aromatic [herbs] / put in the nose facilitate the birth, because they stengthen the force ... AT LAST, remember, that if it will be asked in what period / the birth is easier, I will say at springtime, because it strengthens the force; and if [someone] says the birth is easier in summer /

20 because of [?] and the passage's width, I shall say it would not be enough, for the force is weakened by the fatigue. ${ }^{131}$ / Ibn Sina ${ }^{132}$ wrote in the second book on the woman who has difficult labour, that a half dirham saffron ${ }^{133}$ is good with an ounce of fragrant wine / to quicken the birth, and she will give birth immediately. ${ }^{134}$ And Ibn Nasar ${ }^{135}$ and Rhazes ${ }^{136}$

${ }^{128}$ Ms.P gives only the Hebrew name of the planet: zedeq. Ms. $L$ adds: "called Jupiter, which is brighter ...".

${ }^{129} \mathrm{Ms} . L$ adds: "because [the multipara] has a wider uterus".

130 Both manuscripts use the Arabic name Abuqarat. The Hebrew treatise cites the Hippocratic work On the sperm and on the nature of the child: "In childbirth it is the women who are having their first child who suffer the most, because they have had no experience of the pain; apart from the general discomfort of the body, they suffer most in the loins and the hips, because these become distended. Those who have more experience of bearing children suffer less: much less, if they have a large number of children." Iain M. Lonie, The Hippocratic treatises 'On generation', 'On the nature of the child', 'Diseases IV', Ars medica. II. Abteilung, Griechisch-lateinische Medizin, vol. 7, 2, Berlin, Walter de Gruyter, 1981, On the nature of the child, p. 20. The author used Hippocrates' work directly, and not the Arabic adaptation: Kitäb al-ajinna li-Buqrat: Hippocrates: On embryos (On the sperm \& and On the nature of the child), edited and translated with introduction, commentary and glossary by M. C. Lyons and J. N. Mattock, Cambridge, Pembroke Arabic Texts for the Cambridge Middle East Centre, 1968, p. 14.

${ }^{131}$ Ms.L: "because she has not enough force to breathe". This is the last line in Ms.L. In Ms.P, seventeen more lines were added to the text in a different, but very similar, handwriting. This addition was written with black ink, while the first part was written with brown ink.

132 Hebrew: Abu Sini.

133 Hebrew: za'afran; Arabic za'faran; Crocus sativus, Lat.

134 Ibn Sina, Canon, II: 138 ('On the medical uses of the saffron'). This work has been translated into Hebrew by Yosef Lorki and was published in Naples, 1491 (the chapter on saffron, f. 1036). The language of our manuscripts is very similar to this translation, but neither mentions the use of wine nor gives quantities.

${ }^{135}$ Abū Nașir al Färābī [?] (c. 870-950). See Sarton, op. cit., note 8 above, vol. 1, p. 628.

136 Abū Baker Muhammad ibn Zakariya ar-Rāzi (c. 850-924). See ibid., p. 609. He does not recommend this treatment. 
said that clove-tree ${ }^{137}$ / And saffron with balm ${ }^{138}$ water quicken the birth, and there is no doubt of it. And also fern ${ }^{139}$ leaves and a half dirham / Galia, that is, Alzubeida, ${ }^{140}$ quickens and cures immediately all its diseases, and it is efficient [to cure] pains of a cold uterus, /

25 and also [it is efficient] if she suffers hard abscesses caused by white humour, and it releases the menstrual blood, / and it brings down the suffocated uterus ${ }^{141}$ and it cleans it and brings it to [a state in which it could] conceive. And Rhazes [said] that he who / takes pure frankincense ${ }^{142}$ and gives it to drink to a woman with good wine or with boiled egg quickens the birth, ${ }^{143}$ and there are those / who burn frankincense on a burning coal beneath, and she receives the smoke in her uterus, it is very helpful, and / she has to have an ash-pile ${ }^{144}$ made of rubric ${ }^{145}$ and amber ${ }^{146}$ and aloe-wood ${ }^{147}$ and Labranum, ${ }^{148}$ /

30 storax, calamint, and terebinth, and clove ${ }^{149}$ and mastic, ${ }^{150}$ and this ash-pile made of these / spices strengthen all her forces. And Halaf az-Zahräwi ${ }^{-151}$ [said] that he who makes a very big apple of a dry earth / and hangs it on the woman's neck, she would give birth immediately, and it drives out the placenta. And when he hangs / the apple on her neck, he would put a magnet stone in her hand, and she will be cured. ${ }^{152}$ The experienced ones SAID that / the agate ${ }^{153}$ stone and a coral, ${ }^{154}$ if anyone will give her in a hen soup /

35 or in a good wine to drink, it will cure her and quicken the birth. The white coral ${ }^{155} \| /$ And Aristotle said: Snake skin that was silently stripped when the Sun is in Leo, to make / woman's desire, quickens the birth, ${ }^{156}$ and it is the same with wolf's flesh.

${ }^{137}$ Hebrew: nušqariful; Arabic: qaranful [?]; Eugenia caryophyllata, Lat. Meyerhof, in his commentary on Maimonides' Glossary, noted that this term "designates the aroma of the plant": op. cit., note 95 above, no. 36.

${ }^{138}$ Hebrew: miliša; Melissa officinalis, Lat. Cf. Maimonides, ibid., nos. 40, 47, 255.

139 Hebrew: šarakhi; Arabic: sarahas; Ceterach officinarum, Lat. Cf. Maimonides, ibid., no. 266.

140 Arabic: $\dot{g} a l i a$ and $a z$-zubida or $a z$-zibäd. These are common synonyms for a compound medicament. See: Tuhfat al-Ahbāb, op. cit., note 96 above, no. 157. This medicament was well known in the Middle Ages as efficacious in gynaecological problems. See: Sefer ha-Nisyonot, op. cit., note 62 above, p. 277 : “. . take zabida, which is the secretion of a civet cat, put some of it on cotton wool into the womb; it will clean it thoroughly, and benefit the pregnancy more than other means." Cf. Kroner, op. cit., note 7 above, p. 49.

141 The author of this part in Ms.P, uses the Hebrew term rehem, and not the term em used the first part.

142 Hebrew: levona; Arabic: al-labün. It is a product of Boswellia carterii, Lat. Cf. Maimonides, op. cit., note 95 above, no. 188 .

143 See note 136 , above.

144 Hebrew: tapu'h, "apple”.

145 Hebrew: mušqa; Arabic: mušq and mušaqq. Maimonides, op. cit., note 95 above, no. 238.

146 Hebrew: 'anbara; Arabic: 'anbar. Cf. Tuhfat al-Ahbāb, op. cit., note 96 above, no. 307.

${ }_{147}$ Hebrew: liqanus (read: liganus) alva'is. Cf. Sefer ha-Nisyonot, op. cit., note 62 above, p. 226.

148 Spanish: alunbre[?], alum.

149 Hebrew: guirofli; Spanish: giroflo.

150 Hebrew: maštiq; Arabic: mastikä; derived from the Greek mastikuê. This is a lentisk resin of Pistacia lenticus, Lat. Cf. Maimonides, op. cit., note 95 above, no. 232.

${ }^{151}$ Hebrew: Khaluf al-Zahar. As far as I know, az-Zahrāwi did not recommend such a magical treatment. Cf. Sami Khalaf Hamarneh and Glenn Sonnedecker, A pharmaceutical view of Abulcasis az-Zahräwi in Moorish Spain, Leiden, E. J. Brill, 1963, p. 121; and chapter 75 ('On difficulties of birth'), On surgery and instruments, op. cit., note 68 above, pp. 468-74.

152 It is not clear whether the author also attributes the use of the magnet to az-Zahrāwi. However, this treatment was recommended by 'Ali ibn Saḥl Rabban at-Tabari (ninth century) in his Firdaws al-Hikma fi at-Tibb (Paradise of wisdom on medicine), edited by M. Ż. Siddiqi, Berlin, Sonne, 1928, chapter 160: 'If you put a magnetic stone into the hand of a woman in labour, it will help her in a difficult birth". Cf. note 80, above.

153 The Hebrew text uses a German term: Agastein.

154 Hebrew: qaqabari. The same term appears in Sefer ha-Nisyonot, op. cit., note 62 above.

155 Hebrew: qoral.

${ }^{156}$ A similar magical procedure was recommended by Aḥmad ibn Muhammad al-Baladì (tenth century): "A snake-skin wound around the hips of the woman accelerates the birth." Ullmann, op, cit., note 32 above, p. 109. 